\title{
Health and Cellular Impacts of Air Pollutants: From Cytoprotection to Cytotoxicity
}

\author{
Karine Andreau, Melanie Leroux, and Aida Bouharrour \\ Laboratory of Molecular and Cellular Responses to Xenobiotics, Unit of Functional and Adaptive Biology (BFA), \\ CNRS EAC 4413, University of Paris Diderot, Sorbonne Paris Cité, 75013 Paris, France \\ Correspondence should be addressed to Karine Andreau, karine.andreau@univ-paris-diderot.fr
}

Received 17 November 2011; Revised 17 January 2012; Accepted 18 January 2012

Academic Editor: Etienne Jacotot

Copyright ( $\odot 2012$ Karine Andreau et al. This is an open access article distributed under the Creative Commons Attribution License, which permits unrestricted use, distribution, and reproduction in any medium, provided the original work is properly cited.

Air pollution as one of the ravages of our modern societies is primarily linked to urban centers, industrial activities, or road traffic. These atmospheric pollutants have been incriminated in deleterious health effects by numerous epidemiological and in vitro studies. Environmental air pollutants are a heterogeneous mixture of particles suspended into a liquid and gaseous phase which trigger the disruption of redox homeostasis—-known under the term of cellular oxidative stress-in relation with the establishment of inflammation and cell death via necrosis, apoptosis, or autophagy. Activation or repression of the apoptotic process as an adaptative response to xenobiotics might lead to either acute or chronic toxicity. The purpose of this paper is to highlight the central role of oxidative stress induced by air pollutants and to focus on the subsequent cellular impacts ranging from cytoprotection to cytotoxicity by decreasing or stimulating apoptosis, respectively.

\section{Introduction}

The air is fundamental and essential for living beings but epidemiological studies provide evidences of the harmful impacts of air pollution by increased cardiopulmonary morbidity and mortality as well as reproductive disorders and cancers $[1,2]$. Some air toxics are released from natural sources but most are originated from anthropogenic sources, such as road traffic, construction, industrial, and agricultural activities [3]. Among almost two hundred hazardous air pollutants-mainly corresponding to suspended particulate matter and gases - only six are monitored by the Environmental Protection Agency (EPA) which sets the National Ambient Air Quality Standards (NAAQSs) for air particles, ozone, carbon monoxide, sulfur oxides, nitrogen oxides, and lead (Table 1). In addition, some other air pollutants are subjected to a specific attention because of their deleterious health impacts, like asbestos, mercury, chlorofluorocarbons, and polycyclic aromatic hydrocarbons (PAHs) [4].

At the present time, air pollution is considered as a major inducer of harmful health effects, especially due to solids or liquid droplets suspended in air and termed particulate matter (PM). PMs are usually defined as $\mathrm{PM}_{10}, \mathrm{PM}_{2.5}$ and $\mathrm{PM}_{0.1}$ that correspond to airborne particles with an aerodynamic diameter equal or less than $10,2.5$ and 0.1 microns, respectively. $\mathrm{PM}_{10}$ and $\mathrm{PM}_{2.5}$ are often classified as the "coarse" fraction; $\mathrm{PM}_{2.5}-\mathrm{PM}_{0.1}$ as the "fine" fraction of particles (FP) and $\mathrm{PM}_{0.1}$ correspond to the "ultrafine" fraction of particles (UFP). Although the transition from gasoline to diesel fuel has reduced emissions of carbon monoxide $(\mathrm{CO})$, this has revealed new problems related to the emission of FP, UFP, and diesel exhaust particles (DEP). Engineered nanoparticles (NP), defined as particles having at least one dimension less than $100 \mathrm{~nm}$, are in the same scale in size than atmospheric UFP, but NPs possess specific properties regarding their atomic scale capable of interacting directly with biological molecules. The surface parameter of PM is essential for understanding the biological effects of particulate pollution because size decrease is inversely correlated with the percentage of molecules on the surface and therefore with the surface reactivity. Thus, UFP and NP have a high surface reactivity that is responsible for the production of free radicals, for instance [5]. 
TAble 1: Air pollutants. The National Ambient Air Quality Standards (NAAQSs) are set by the Environmental Protection Agency under authority of the Clean Air Act and define the maximum allowable concentrations of outdoor air pollutants in the USA. Units of NAAQS are parts per million (ppm) by volume, parts per billion (ppb-1 part in 1,000,000,000) by volume, milligrams per cubic meter of air $\left(\mathrm{mg}^{\mathrm{m}} / \mathrm{m}^{3}\right.$ ), and micrograms per cubic meter of air $\left(\mu \mathrm{g} / \mathrm{m}^{3}\right)$. Average time refers to time for which the values of NAAQS should not be exceeded in the ambient air [14-16].

\begin{tabular}{|c|c|c|c|}
\hline \multirow{2}{*}{ Pollutants } & \multirow{2}{*}{ Main sources } & \multicolumn{2}{|c|}{ NAAQS } \\
\hline & & Level & Average time \\
\hline Asbestos & $\begin{array}{l}\text { Electrical and building insulation } \\
\text { (fiber cement) }\end{array}$ & & \\
\hline Carbon dioxide $\left(\mathrm{CO}_{2}\right)$ & Fossil fuel combustion & & \\
\hline Carbon monoxide (CO) & $\begin{array}{l}\text { Incomplete combustion, exhaust from motor } \\
\text { vehicles, emissions from certain industrial } \\
\text { processes (agglomeration of ore, steel, waste } \\
\text { incineration) }\end{array}$ & $\begin{array}{l}35 \mathrm{ppm}\left(10 \mathrm{mg} / \mathrm{m}^{3}\right) \\
9 \mathrm{ppm}\left(10 \mathrm{mg} / \mathrm{m}^{3}\right)\end{array}$ & $\begin{array}{l}1 \text { hour } \\
8 \text { hours }\end{array}$ \\
\hline $\begin{array}{l}\text { Chlorofluorocarbons } \\
\text { (CFCs) }\end{array}$ & $\begin{array}{l}\text { Use in consumer goods (aerosol propellants, } \\
\text { foams, fire extinguishers, refrigerants) }\end{array}$ & & \\
\hline $\begin{array}{l}\text { Dioxins and dioxin-like } \\
\text { compounds }\end{array}$ & Byproducts of various industrial processes & & \\
\hline $\begin{array}{l}\text { Polychlorinated } \\
\text { dibenzo-p-dioxins } \\
\text { (PCDDs) }\end{array}$ & $\begin{array}{l}\text { Waste incineration, metal smelting and } \\
\text { refining, chlorinated pesticides, and herbicides }\end{array}$ & & \\
\hline $\begin{array}{l}\text { Polychlorinated } \\
\text { dibenzofurans (PCDFs) }\end{array}$ & $\begin{array}{l}\text { Environmental accidents contamination, waste } \\
\text { incineration, chlorinated pesticides, and } \\
\text { herbicides }\end{array}$ & & \\
\hline $\begin{array}{l}\text { Polychlorinated biphenyls } \\
\text { (PCBs) }\end{array}$ & $\begin{array}{l}\text { Used as coolants and insulating fluids for } \\
\text { transformers and capacitors, and as plasticizers } \\
\text { in paints and cements, additives in flexible PVC } \\
\text { coatings }\end{array}$ & & \\
\hline Hydrogen sulfide $\left(\mathrm{H}_{2} \mathrm{~S}\right)$ & Paper pulp production and oil refineries & & \\
\hline Methane $\left(\mathrm{CH}_{4}\right)$ & $\begin{array}{l}\text { Coal mines exploitation, garbage landfills, } \\
\text { livestock, gas distribution }\end{array}$ & & \\
\hline Nitrogen dioxide $\left(\mathrm{NO}_{2}\right)$ & & $\begin{array}{l}100 \mathrm{ppb} \\
53 \mathrm{ppb}\end{array}$ & $\begin{array}{l}1 \text { hour } \\
\text { Annual }\end{array}$ \\
\hline \multicolumn{4}{|l|}{ Nitrogen monoxide (NO) } \\
\hline Nitrogen oxides (NOx) & $\begin{array}{l}\text { Fossil fuel combustion, industrial processes } \\
\text { (nitric acid production, fertilizer } \\
\text { manufacturing, surface treatment) }\end{array}$ & & \\
\hline Nitrous oxide $\left(\mathrm{N}_{2} \mathrm{O}\right)$ & $\begin{array}{l}\text { Fossil fuel combustion, some industrial } \\
\text { processes, motor vehicles, soils, and oceans }\end{array}$ & & \\
\hline Ozone $\left(\mathrm{O}_{3}\right)$ & $\begin{array}{l}\text { Tropospheric ozone formed from reaction } \\
\text { between UV, NOx, and VOC }\end{array}$ & $\begin{array}{c}0.12 \mathrm{ppm}\left(235 \mu \mathrm{g} / \mathrm{m}^{3}\right) \\
0.075 \mathrm{ppm}\left(150 \mu \mathrm{g} / \mathrm{m}^{3}\right)\end{array}$ & $\begin{array}{l}1 \text { hour } \\
8 \text { hours }\end{array}$ \\
\hline \multicolumn{4}{|l|}{ Particulate matter (PM) } \\
\hline $\mathrm{PM}_{10}$ & $\begin{array}{l}\text { Natural dust, sea salt, industrial, agriculture, } \\
\text { and forestry activities }\end{array}$ & $150 \mu \mathrm{g} / \mathrm{m}^{3}$ & 24 hours \\
\hline $\mathrm{PM}_{2.5}$ & $\begin{array}{l}\text { Fossil fuel combustion, road traffic, and other } \\
\text { transports, agriculture, and manufacturing }\end{array}$ & $\begin{array}{c}35 \mu \mathrm{g} / \mathrm{m}^{3} \\
15.0 \mu \mathrm{g} / \mathrm{m}^{3}\end{array}$ & $\begin{array}{l}24 \text { hours } \\
\text { Annual }\end{array}$ \\
\hline $\mathrm{PM}_{0.1}$ & $\begin{array}{l}\text { Residential heating, road transport, } \\
\text { manufacturing, agriculture, waste processing } \\
\text { plants }\end{array}$ & & \\
\hline $\begin{array}{l}\text { Polycyclic aromatic } \\
\text { hydrocarbons (PAHs) }\end{array}$ & $\begin{array}{l}\text { Incomplete combustion of organic material } \\
\text { (wood burning, fossil fuel combustion, etc.) }\end{array}$ & & \\
\hline \multirow{3}{*}{ Sulfur dioxide $\left(\mathrm{SO}_{2}\right)$} & \multirow{3}{*}{$\begin{array}{l}\text { Sulfur-containing fossil fuel combustion (coal, } \\
\text { lignite, petroleum coke, heavy fuel oil, heating } \\
\text { oil, diesel), }\end{array}$} & 75 ppb & 1 hour \\
\hline & & $0.14 \mathrm{ppm}\left(365 \mu \mathrm{g} / \mathrm{m}^{3}\right)$ & 24 hours \\
\hline & & $0.030 \mathrm{ppm}\left(80 \mu \mathrm{g} / \mathrm{m}^{3}\right)$ & Annual \\
\hline
\end{tabular}


Table 1: Continued.

\begin{tabular}{|c|c|c|c|}
\hline \multirow{2}{*}{ Pollutants } & \multirow{2}{*}{ Main sources } & \multicolumn{2}{|c|}{ NAAQS } \\
\hline & & Level & Average time \\
\hline \multicolumn{4}{|l|}{ Toxic metals } \\
\hline Antimony (Sb) & $\begin{array}{l}\text { miscellaneous plastics manufacturing, } \\
\text { petroleum products, and fabricated structural } \\
\text { metal products, thermal power generation }\end{array}$ & & \\
\hline Arsenic (As) & Heavy fuel oil combustion & & \\
\hline Cadmium (Cd) & $\begin{array}{l}\text { Waste incineration, heavy fuel oil, and biomass } \\
\text { burning }\end{array}$ & & \\
\hline Chromium (Cr) & $\begin{array}{l}\text { Production of glass, cement, ferrous } \\
\text { metallurgy, and foundries }\end{array}$ & & \\
\hline Cobalt (Co) & Nuclear facilities, production of steel and alloys & & \\
\hline Copper $(\mathrm{Cu})$ & $\begin{array}{l}\text { Combustion and waste treatment, processes of } \\
\text { ferrous and nonferrous metallurgy }\end{array}$ & & \\
\hline Lead $(\mathrm{Pb})$ & Road transport, electric batteries production & $0.15 \mu \mathrm{g} / \mathrm{m}^{3}$ & Rolling 3 Months \\
\hline Mercury (Hg) & $\begin{array}{l}\text { Coal and oil burning, chlorine production, } \\
\text { incineration of household, and industrial waste }\end{array}$ & & \\
\hline Nickel (Ni) & Heavy fuel oil combustion & & \\
\hline Selenium (Se) & Glass production, heavy fuel oil combustion & & \\
\hline Vanadium $(\mathrm{V})$ & Oil refineries, combustion of fossil fuels & & \\
\hline Zinc $(\mathrm{Zn})$ & $\begin{array}{l}\text { Coal and heavy fuel combustion, ferrous and } \\
\text { nonferrous metallurgy, waste incineration }\end{array}$ & & \\
\hline $\begin{array}{l}\text { Volatile organic } \\
\text { compounds (VOCs) }\end{array}$ & $\begin{array}{l}\text { Road transport, industrial processes involving } \\
\text { the use (basic and fine chemicals, metal } \\
\text { degreasing, paint application, printing, } \\
\text { adhesives, rubber, etc.), or not of solvents } \\
\text { (petroleum refining, use of CFCs, production } \\
\text { of alcoholic beverages), household products }\end{array}$ & & \\
\hline
\end{tabular}

The chemical composition of PM varies according to environmental parameters (weather, continental, and/or regional influences) as well as to size. Indeed, $\mathrm{PM}_{10}$ are fragments from other larger particles observed during localized pollution episodes in urban areas and that may also include some pollen, spore, and plant. $\mathrm{PM}_{10}$ come from several sources like road transport, industrial, or construction activities [6] (Table 1). The urban aerosol mainly contains fine and ultrafine particles which consist of a core of elemental carbon from fossil fuel combustion and termed soots. Some inorganic components (ammonium, chloride, sulfates, nitrates, and metals), organic compounds-such as alkan, alkanoic acid, aliphatic acid, quinone, and PAHs - and biological species are adsorbed onto this carbon core [7].

The size of particles is directly linked to their deleterious potential on health. Indeed, FP, UFP, and DEP are inhaled with the air, penetrate deeply into the respiratory tract, and are mainly deposited in tracheobronchial and alveolar regions [5]. Industrial air pollution was clearly related to increased mortality and morbidity from respiratory and cardiovascular origin during episodes of heavily polluted fog (smog) in London in 1952 and the Ruhr in 1985 associated with 4,000 to 120,000 premature deaths, respectively, and an $8 \%$ increase in daily mortality. In addition, exposure to $\mathrm{PM}_{2.5}, \mathrm{PM}_{10}, \mathrm{SO}_{2}$, and black smoke has been shown as being responsible for asthma exacerbation in both adults and children [8]. The International Agency for Research on Cancer (IARC) classifies DEP as a possible carcinogen (Group 2A) [9]. Thus, epidemiological studies show that occupational exposure of truck drivers is associated with an increased incidence of lung cancer [10]. Based on the statistical model of an American study, the French Agency of Environmental and Occupational Health Safety (AFSSET) estimated in 2002 that 1117 lung cancer deaths were caused by $\mathrm{PM}_{2.5}$ exposure, a fraction of $11 \%$ [11]. Unlike the shortterm effects linked to an inflammatory response, impacts of $\mathrm{PM}$ on carcinogenesis come from prolonged exposure. When mucociliary and alveolar clearance functions are exceeded, PM persist into lungs, leading to thickening of bronchial walls, an airway remodeling characterized by the hyperplasia of goblet and smooth muscle cells and a subepithelial fibrosis, as has been demonstrated in asthma and COPD (Chronic Obstructive Pulmonary Disease) [12]. Thereby, PM may act directly on the respiratory epithelium causing a range of various deteriorations to the total desquamation. To overcome this, the self-renewal of stem cells is accelerated, but proliferation and differentiation processes may escape to control and these adult lung stem cells are now considered as lung tumor initiators (see for review [13]). Given that the modulation of apoptotic cell death is an essential step in tumor initiation and promotion, this paper will focus on the molecular mechanisms of both induction and resistance 
to apoptosis with a particular attention to mitochondria, the main executor (or executioner) of apoptosis.

\section{Apoptosis}

Since the remarkable scientific advances on the knowledge of cell death process, necrosis is not anymore considered as the only consequence of exposure to the toxic air pollutants. Indeed, impacts on activation or repression of apoptosis are now better described [17] and numerous in vitro studies demonstrated the modulation of apoptosis by environmental air pollutants including heavy or transition metals [18-20], carbon monoxide [21], and nondioxin-like PCBs (polychlorinated biphenyls) [22]. Apoptosis is a programmed cell death defined by morphological alterations (for review see [23]) leading to the progressive condensation of the cell into apoptotic bodies containing organelles or cytoplasmic fragments that are rapidly recognized and engulfed by neighboring cells and macrophages. The late-morphological changes are accompanied by biological alterations, such as the modification of lipid composition of the plasma membrane and permeability $[24,25]$, or the activation of various enzymes (e.g., phospholipase A2, DNase II, the caspaseactivated DNase (CAD) [26], endonuclease G (EndoG) [27], the apoptosis-inducing factor (AIF) [28, 29]) leading to DNA fragmentation. All these apoptotic features may require activation of specific proteases called Caspases-for "cysteinyl aspartate-cleaving protease" - a family of proteins containing at least fourteen members in mammalians, eight of them actively participate to the execution of apoptosis while the others are involved in inflammation [30]. Under normal conditions, initiator Caspases-2, -8, -9, and -10 are expressed as inactive zymogens with a large N-terminal prodomain required for their autocatalytic activation into a tetrameric enzyme. When activated, the initiator caspase activates some executioner Caspases-3, -6, and -7, which in turn cleave specific substrates thus modifying multiple cellular functions such as DNA repair (DNA-PK, U1-70 kD, PARP), chromatin condensation (inhibitor of CaspaseActivated DNAse), or cytoskeleton stability ( $\alpha$-Fodrin, Lamin A, Actin); for review see [31].

The apoptotic cell death and caspases activation are mainly elicited by extrinsic and intrinsic pathways which are initiated by death receptors and intracellular events leading to mitochondrial dysfunction, respectively. In the extrinsic pathway, ligands of death receptors belonging to "tumour necrosis factor receptor" family (TNFR) promote formation of the multimolecular complex termed DISC (deathinducing signalling complex) [32] through the recruitment of adaptor proteins FADD (Fas-associated protein with death domain) and/or TRADD (TNF-receptor-associated death domain protein) and the subsequent activation of Caspase8 and executive caspases.

In the intrinsic pathway (also called "mitochondrial pathway"), stimuli from different intracellular pathways (e.g., withdrawal of growth factors, exposure to toxins, hypoxia, bacterial or viral infections, physical or chemical stressors) converge on mitochondrial alterations that are the point of no return in apoptotic cell death. As reviewed elsewhere, permeabilization of outer and inner mitochondrial membranes (MMP) constitutes the limited and controlled step of the executive phase of apoptosis [33, 34]. In healthy cells, inner membrane (IM) is impermeable to protons in order to maintain the $\mathrm{H}^{+}$gradient necessary to oxidative phosphorylations (OXPHOS) and mitochondrial transmembrane potential $(\triangle \Psi \mathrm{m})$. In dying cells, the IM's permeability increases to solutes less than $1.5 \mathrm{kDa}$ and leads to the permeability transition caused by the opening of permeability transition pore complex (PTP) [35]. Despite a lack of consensus on the exact composition of the PTP, several proteins directly or indirectly constitute this complex such as the outer membrane- (OM-) inserted voltage-dependent anion channel (VDAC), the IM-located ANT (adenine nucleotide translocator), and the cyclophilin $\mathrm{D}$ in the mitochondrial matrix [36]. There is four isoforms of ANT (ANT 1-4) and three isoforms of VDAC (VDAC 1-3) that have antagonist effects on apoptosis, since VDAC1, ANT1, and ANT3 are proapoptotic proteins, while VDAC2, ANT2, and ANT4 are able to protect cells from death. In addition, several regulators interact closely with the PTP core proteins, in particular Hexokinase II, the translocator protein (TSPO), and Creatine Kinase which interact with VDAC in cytosol, outer membrane, and intermembrane space (IMS), respectively $[35,37,38]$. PTP opening can also be modulated via chemical modifications of PTP partners or through interaction with several pro- or antiapoptotic proteins. Indeed, thiols oxidation of ANT protein or proapoptotic members of the Bcl-2 family (i.e., Bax, Bak, and t-Bid) are well-known inducers of MMP [39, 40]. Generally, PTP opening and subsequent MMP results in $\triangle \Psi \mathrm{m}$ dissipation associated with superoxide anion's production, swelling of the mitochondrial matrix as a consequence of the massive entry of water and solutes, and the release of many proapoptotic proteins from the IMS to the cytoplasm including Cytochrome $c$, Smac/DIABLO, and Omi/HtrA2 which participate to the caspase-dependent apoptotic pathway $[41,42]$. Released Cytochrome $c$ participates to the formation of a multiprotein complex termed "apoptosome" via physical interaction with the adaptor molecule Apaf-1 (apoptosis protease activating factor 1), the executioner procaspase-9, and ATP/dATP [43-46]. Furthermore, a caspase-independent apoptotic pathway can be activated by mitochondrial proteins AIF and EndoG that migrate towards nucleus to perform DNA fragmentation [33].

This mitochondrial central step may be positively or negatively modulated by Bcl-2 family proteins which mainly act through regulation of OM's permeabilization and Cytochrome $c$ release. The Bcl-2 family contains three groups corresponding to prosurvival proteins (Bcl-2, Bcl- $\mathrm{x}_{L}, \mathrm{Bcl}-$ w, Mcl-1, and A1/Bfl1), proapoptotic effectors (Bax, Bak), and a third subfamily called BH3-only proteins (Bad, Bik, Hrk, Bid, Bim, Bmf, Noxa, and Puma) which modulates activation of both first groups. The upregulation of Bcl-2 or other antiapoptotic members and/or the downregulation of Bax/Bak proteins have been reported to impair MMP and apoptosis underlying their fundamental role in the state of life versus cell death [47]. Thereby, Strasser et al. proposed a new mechanistic model of how Bax and Bak could promote 
MMP, directly or indirectly; for review see [48]. Otherwise, the antiapoptotic proteins of the Bcl-2 family might inhibit cell death and MMP through two additional mechanisms: (i) the potential interaction with Apaf-1 protein leading to diminution of apoptosome formation or (ii) the direct inhibition of mitochondrial permeabilization. However the fact that $B c l-x_{L}$ might neutralize Apaf-1's function is still controversial, since data from different studies showing an inhibitory interaction between $\mathrm{Bcl}-\mathrm{x}_{L}$, Caspase- 9 , and Apaf$1[49,50]$ were rapidly refuted $[51,52] . \mathrm{Bcl}-2$ and $\mathrm{Bcl}-\mathrm{x}_{L}$ are related to some bacterial proteins and data demonstrated their ability to form pores into membranes, to prevent the proton efflux triggered by calcium or reactive oxygen species (ROS) and the maintenance of mitochondrial ADP/ATP exchange [53, 54]. Bcl-2 also prevents excessive ROS production and impacts of the subsequent oxidative stress [55].

As a source and a cellular target of ROS, mitochondria regulate glucose metabolism, differentiation, or cell death and might play an important role in tumorigenesis. Currently, a new emerging concept considers mitochondrion as a ROS-signaling integrator $[56,57]$. Mitochondrion is the site of OXPHOS by which ATP is formed by coupling with the electrons' transfer from a donor (NADH or FADH2) to the final acceptor oxygen of the mitochondrial respiratory chain. However, about $2 \%$ of the electrons escape from sites in complex I and/or complex III to react directly with oxygen thus generating superoxide anion $\left(\mathrm{O}_{2}{ }^{--}\right)$[56]. This leakage of electrons may appear in hypoxia conditions but could also participate under physiological conditions to various signaling pathways, since $\mathrm{O}_{2}{ }^{--}, \mathrm{H}_{2} \mathrm{O}_{2}$ (hydrogen peroxide) and $\mathrm{HO}^{\circ}$ (hydroxyl radical) are considered as intracellular messengers. Mitochondria seem to be the most potent intracellular source of ROS since the mitochondrial matrix concentration of $\mathrm{O}_{2}{ }^{--}$was estimated to be 5- to 10 -fold higher than that in the cytosol [58]. The Mn-superoxide dismutase (SOD) localized in the mitochondrial matrix rapidly dismutes $\mathrm{O}_{2}{ }^{--}$in $\mathrm{H}_{2} \mathrm{O}_{2}$ which in turn can be decomposed by Catalase or may interact with $\mathrm{O}_{2}{ }^{\bullet-}$ by the Haber-Weiss reaction, or with $\mathrm{Fe}^{2+}\left(\mathrm{or} \mathrm{Cu}^{+}\right)$by the Fenton reaction, leading to the generation of $\mathrm{HO}^{\circ}$. The mitochondrial ROS generation can be responsible for activation of death pathways by inducing (i) nuclear and mitochondrial DNA damages (i.e., formation of 8-hydroxydeoxyguanosine) leading to p53-dependent cell death [59], (ii) activation of signaling pathways involving NF- $\kappa \mathrm{B}$, JNK, or p38 MAPK $[60,61]$, (iii) MMP increase and $\mathrm{Ca}^{2+}$-induced PTP opening $[39,62]$, and (iv) Cytochrome $c$ release by oxidation of the anionic phospholipid cardiolipin $[63,64]$. Nevertheless, mitochondrial ROS can also participate to protection against apoptosis by activation of antioxidant systems such as GSH (L- $\gamma$-glutamylL-cysteinylglycine) and multiple GSH-linked antioxidant enzymes (i.e., Gluthatione Peroxidases 1 and $4[65,66]$, Glutaredoxin $2[67,68]$, Glutathione S-transferase $\alpha[69]$ ).

\section{Air Pollutants and Cytotoxic Cell Death}

Apoptosis is one of the possible consequences of acute or chronic exposure to air pollutants and various toxicants- such as PM, metals, and pesticides-are capable to target mitochondria, directly or indirectly [70-72]. For instance, rotenone which is used as pesticide inhibits the mitochondrial complex I. In addition, other pesticides such as pentachlorophenol and 2,4-dinitrophenol (DNP) induce cytotoxicity by uncoupling ATP synthesis and the mitochondrial $\mathrm{H}^{+}$gradient. Indeed, the small lipophilic molecule DNP captures and carries protons out of the IMS leading to the $\mathrm{H}^{+}$accumulation into the matrix and the disruption of the $\mathrm{pH} / \mathrm{H}^{+}$gradient [73].

Although many studies describe the ability of air pollutants to trigger some characteristic features of apoptosis, only few detailed mechanistic studies have been published, the majority focusing solely on the oxidative stress emergence as a result of the unbalance between ROS production and activation of antioxidant defenses. Indeed, publications dealing with the cytotoxic consequences of airborne particles showed an induction of apoptosis associated with cellular stress, ROS production [74], $\Delta \Psi \mathrm{m}$ drop, caspases activation [75], and DNA fragmentation [70, 76, 77]. The cell death often demonstrated in experiments performed with PM in normal human lung tissue or airway epithelial cells was a mitochondria-mediated apoptosis, characterized by a marked reduction of mitochondrial dehydrogenase activity and the cytoprotective effects of mitochondrial inhibitors (e.g., rotenone, DIDS) [78, 79]. Cytochrome $c$ release, activation of caspases- 9 and -3 , and PARP-1 cleavage were also observed after exposure to urban and industrial $\mathrm{PM}_{2.5}$ in correlation with the induction of an oxidative stress studied by formation of 8 -hydroxy-2'-desoxyguanosine ( 8 -OHdG) $[78,80]$. Thus, short-term exposure studies performed in respiratory cells with high doses of PM or its components led to a consensus that health effects as well as cytotoxic impacts of particulate pollution mainly involve ROS production and oxidative stress (Figure 1) [81, 82].

Increased production of ROS was first clearly identified as the central step of the proinflammatory response (GM-CSF, IL-6, IL-8, TNF- $\alpha$ ) induced upon exposure to air pollutants via ROS-sensitive transcription factors such as NF- $\kappa \mathrm{B}$ and AP-1 $[82,85]$. Actually, particulate pollutants are considered as potent oxidants, and the induced intrinsic pathway of apoptosis may be associated with oxidative stress generated from organic (i.e., PAHs, nitro-PAHs/ketones/quinones) as well as inorganic compounds adsorbed on the surface of particles [84, 86-88]. Thus, PAHs induced-apoptosis is mainly mediated via the mitochondrial pathway (Caspase- 3 activation, AIF, and EndoG release) in a p53-dependent manner in hepatic cells and macrophages [89-91], even if the causal relationship between genotoxic effects of $\mathrm{BaP}$ and induction of apoptosis is not established for all cell types [92]. Organic components are able to mimic the apoptogenic impact of PM in various cell types through activation of the aryl hydrocarbon receptor (AhR). AhR is a cytoplasmic ligand-dependent transcription factor which translocates to the nucleus in order to bind specific Xenobiotic Responsive Elements in target genes promoters, leading to activation of phase I and II metabolizing enzymes and contributing to detoxification. For instance, phase I enzymes such as cytochrome $\mathrm{P} 450$ oxidase $1 \mathrm{~A} 1$ produce 


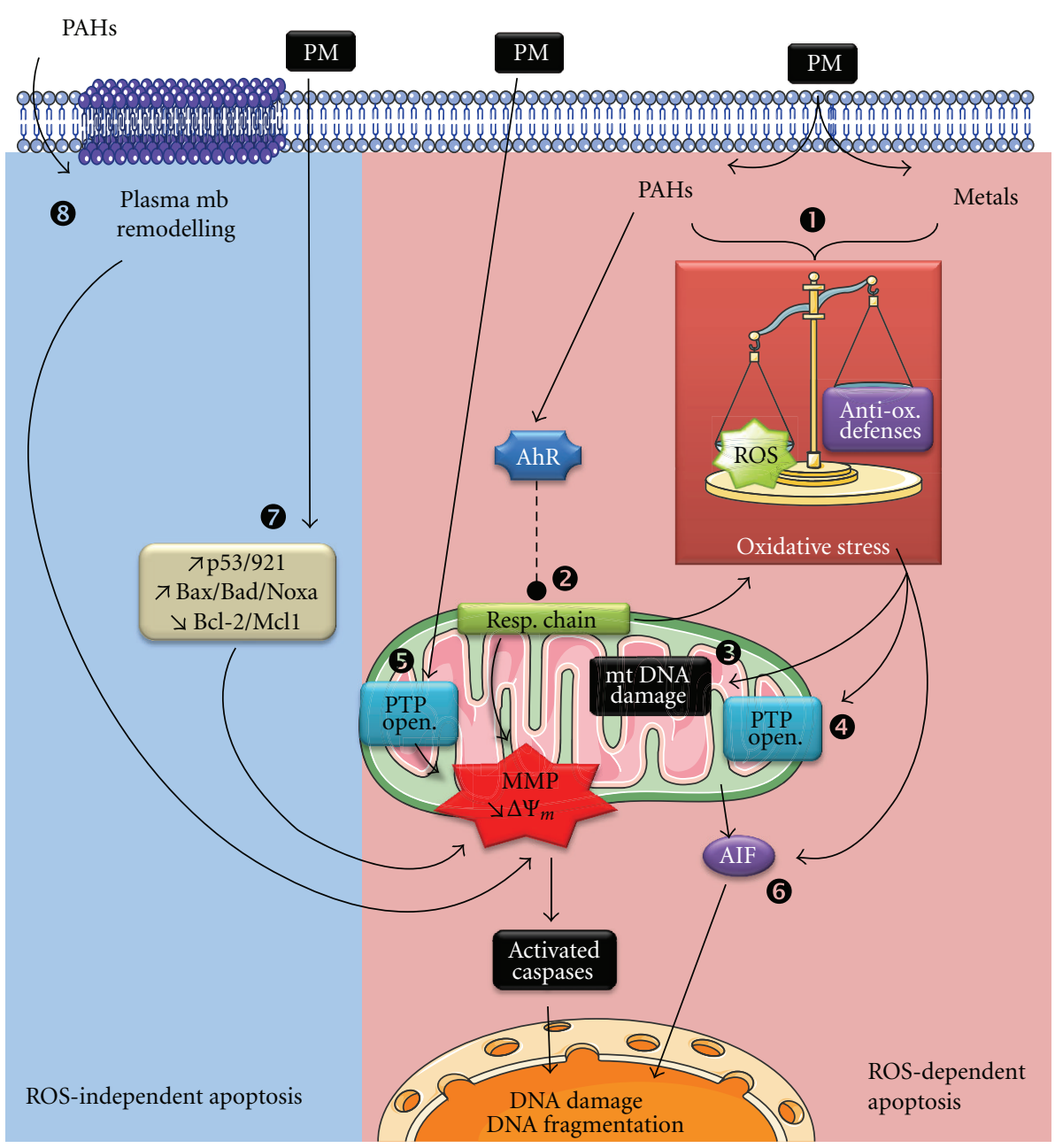

FIGURE 1: ROS-dependent and -independent apoptosis induced by particulate pollutants. Particulate matter (PM) or their compounds (PAHs and metals) provoke apoptotic cell death through ROS-dependent (pink zone) or ROS-independent (blue zone) pathways. Actually, particulate pollutants are considered as potent ROS generators from organic (i.e., PAHs) or metallic compounds (1) and leading to oxidative stress as the result of the unbalance between ROS production and activation of antioxidant defenses. Senft et al. demonstrated that AhR activation might regulate the mitochondrial respiratory chain function and induce production of $\mathrm{O}_{2}{ }^{--}$and $\mathrm{H}_{2} \mathrm{O}_{2}$ from mitochondria ([83], (2)). As a consequence of oxidative stress, mitochondria are harmed by ROS that are responsible for damage of mitochondrial DNA (3), mitochondrial lipid peroxidation, and opening of PTP complex (PTP open. (4)). Mitochondrial membrane permeabilization (MMP) and PTP opening might also be a direct effect of diesel particles on isolated mitochondria ([84], (5)). As an additional pathway of the ROSdependant apoptosis induced by air pollutants, the apoptogenic activity of AIF might be enhanced by xenobiotics, air pollutants, or their ROS derivatives (6). Some other ROS-independent signaling pathways have been identified such as the upregulation of proapoptotic proteins and/or the repression of prosurvival Bcl-2 family proteins (7). Recent publications also demonstrated a new mechanism of apoptosis triggered by PAHs through alterations of lipid rafts' composition and remodeling of the plasma membrane (8). Illustrations carried out thanks to Servier Medical Art.

$\mathrm{H}_{2} \mathrm{O}_{2}$ by metabolizing benzo(a)pyrene (BaP) [93] into a reactive intermediate (anti-7,8-dihydrodiol-9,10-epoxybenzo(a)pyrene, BPDE) [94] known to trigger DNA damage and carcinogenesis [95]. In vivo studies performed in mice exposed to TCDD (2,3,7,8-tetrachlorodibenzo- $p$-dioxin) showed an important oxidative response in correlation with the high affinity of the TCDD-AhR binding, suggesting a strong link between oxidative stress, Ah receptor, and its target genes CYP1A1 and 1A2 [96].

In this context, Senft et al. were interested to understand the involvement of $\mathrm{AhR}$ in mechanisms responsible for the dioxin-induced mitochondrial oxidative stress. These authors reported that liver mitochondria from mice exposed to TCDD $(15 \mathrm{mg} / \mathrm{kg})$ during three consecutive days showed a decrease of aconitase activity as a marker of mitochondrial ROS production, a mitochondrial generation of $\mathrm{O}_{2}{ }^{--}$and $\mathrm{H}_{2} \mathrm{O}_{2}$ in the presence of succinate, as well as an activation of glutathione peroxidase-1 and glutathione reductases [83]. Interestingly, AhR knockout mice are protected from TCDDinduced ATP depletion, production of ROS, and the resultant oxidative stress response, suggesting that AhR might regulate the activity of mitochondrial electron transport 
chain, especially the complexes III (stimulation) and IV (inhibition), and that the major source of the direct AhRmediated oxidative stress response has a mitochondrial origin.

Furthermore, mitochondrion may be a site of ROS generation also in response to metallic environmental pollutants, as shown with cadmium or hexavalent chromium that trigger ROS production from the electron transfer chain as well as from the NADPH oxidase activity $[97,98]$. In addition to organic compounds, heavy and transition metals such as vanadium, cadmium, mercury, lead, aluminum, titanium, chromium, iron, cobalt, nickel, copper, and zinc are often found in atmospheric pollutants and measured as adsorbed inorganic compounds on FP and UFP. Metals affect human health, especially when these toxicants compete with essential elements and thus modify many cellular processes [99]. Some metals are janus elements since they are both prominent inducers of ROS and essential cofactors for some antioxidant enzymes. As reviewed by Pulido and Parrish, transition metals promote apoptosis through ROS generation, mitochondria dysfunction, activation of MAPK, p53 and caspases, or downregulation of antiapoptotic proteins of Bcl-2 family [100]. Metals and the water-soluble fractions of $\mathrm{PM}$ are also known to cause inflammation and cancer mostly due to DNA damage as a consequence of ROS generation by Fenton reaction (see Section 2). Indeed, carcinogenic metals (i.e., As, Cd, Cr, Ni) promote apoptosis with DNAbase modifications, strand breaks and rearrangements [101]. Generation of ROS, decrease of intracellular GSH, accumulation of $\mathrm{Ca}^{2+}$, loss of $\Delta \Psi \mathrm{m}$, upregulation of Caspase-3, downregulation of $\mathrm{Bcl}-2$, and deficiency of $\mathrm{p} 53$ protein led to arsenic-induced apoptosis [102, 103]. In case of cadmium, metallothionein expression determines the cell death fate (between apoptosis and necrosis), but Cd-induced apoptosis is due to inhibition of antioxidant enzymes, mitochondrial dysfunction [104], and PTP opening, probably through its interaction with thiol groups of ANT [105], whereas ROS and p53 contribute to apoptosis caused by chromium and selenium [106-108]. In addition, PM containing high levels of noncarcinogenic metals (i.e., cobalt, lead, iron, and zinc) were often shown to provoke ROS production (e.g., $\mathrm{H}_{2} \mathrm{O}_{2}$ ) leading to apoptosis through the mitochondrial pathway [109-113]. Under apoptotic conditions, zinc is also able to increase p53 expression and function probably by stabilizing this protein which contains a tightly bound zinc atom necessary for its DNA binding activity $[114,115]$.

As a consequence of oxidative stress, mitochondria are often damaged by ROS and experiments performed on HepG2 cells and liposomes clearly showed that $\mathrm{O}_{2}{ }^{--}$ alone seems to elicit apoptosis and a rapid and massive release of Cytochrome $c$ independently of PTP opening but rather through a VDAC-dependent permeabilization of the outer mitochondrial membrane [116]. These results are in contradiction with those obtained by Xia et al. which performed, to the best of our knowledge, the only study of the prospective direct effect of Diesel particles on mouse liver-isolated mitochondria [84]. Xia et al. showed that the aromatic fraction of DEP can directly induce mitochondria swelling and depolarization leading to calcium overload in matrix [84]; this might be related to the massive decrease of the content in cardiolipin published earlier [117]. As mitochondrial swelling can be due to the long-lasting opening of PTP or the closure of VDAC, Xia et al. assessed the effect of the PTP inhibitor cyclosporine A (CsA) and demonstrated its ability to counteract DEP-induced swelling, suggesting that these organic compounds may directly promote PTP-mediated MMP [84]. In addition, oxidation of cardiolipin may be a crucial event of cell death triggered by xenobiotics as demonstrated by in vivo inhalation exposure to single-walled carbon nanotubes and in vitro experiments of LPS-induced apoptosis on pulmonary artery endothelial cells. Indeed, cardiolipin hydroperoxides and their hydroxyderivatives are prominently accumulated in inflammatory, apoptotic, and oxidative stress conditions [118]. However, mitochondrial lipid peroxidation is not the only oxidative stress consequence responsible for mitochondria-driven apoptosis since $\mathrm{O}_{2}{ }^{--}$and $\mathrm{H}_{2} \mathrm{O}_{2}$ can damage proteins as well as mitochondrial DNA. Mitochondrial DNA (mtDNA) is one of the main targets of mitochondrial ROS due to the close proximity of site production and the lack of protective histones. TCDD at low doses was shown to induce preferentially mitochondrial versus nuclear genotoxicity as assessed by $8-\mathrm{OHdG}$, reduction in mtDNA number, and increase in mtDNA deletions $[119,120]$.

As an additional pathway of the ROS-dependent apoptosis induced by air pollutants, the apoptogenic activity of AIF is controlled by the redox status as oxidized monomers have higher DNA affinity than NADH-reduced dimers [121]. Mitochondrial AIF is a NADH-dependent oxidoreductase containing a flavin adenine dinucleotide (FAD) and which is tethered to the inner membrane of mitochondria and participates to the caspase-independent pathway of apoptosis. However, a recent published data demonstrated that AIF has a quinone reductase activity that is around thousandfold lower than Cytochrome P450 or NADPH:quinone oxidoreductase (NQO1) normally involved in the phases I and II of the xenobiotic detoxification processes [122]. This suggests that interaction of AIF with xenobiotics, air pollutants, or their ROS derivatives might promote its oxidized form and enhance its apoptogenic activity. Thereby, apoptosis induced by PM or wood smoke extracts on human alveolar macrophages and pulmonary artery endothelial cells was associated with AIF upregulation and its translocation to nucleus $[123,124]$. In addition to the mitochondrial pathway, different studies also demonstrated that the extrinsic pathway of apoptosis (with TNF- $\alpha$ secretion, caspases- 8 and -3 activation) is involved in the cytotoxic impacts of FP, UFP, and NP [125-127]. Data published in 2006 showed that apoptosis induced by fine particles in the lung epithelial cells has taken place in parallel with the induction of proliferation and that the two antagonistic phenomena appear to be induced by oxidative stress or EGFR [127, 128]. Finally, posttranslational oxidative modifications of proteins (i.e., nitrosylation, hydroxylation, glutathionylation of cystein residues) have been shown to promote aberrant activation of signal transduction cascades. Among these pathways, modulation of kinases ASK/JNK, Akt, or MAPK, or transcription factors $\mathrm{Nrf} 2, \mathrm{NF} \kappa \mathrm{B}, \mathrm{AP}-1$, and $\mathrm{p} 53$ was clearly 
demonstrated following exposure to various environmental pollutants whose cellular effects are establishment of both an inflammatory and an apoptotic response [80, 129-132].

Through all examples cited previously, it is clear that cytotoxicity of air pollutants (PM, PAHs, metals, or herbicides) in various cells $[70,78,133]$ mainly incriminates the excessive production of ROS capable of targeting mitochondria by different mechanisms (Figure 1) [83, 134]. At the same time as the ROS-dependent apoptosis, some other oxidative stress-independent signaling pathways have been identified. For instance, different PM were shown to upregulate the expression of potent regulators of the mitochondrial checkpoint such as p53 and its targets p21, Noxa, Bax, Bad, and Bim in parallel to the repression of Bcl-2 and Mcl-1 [70, 78, 125, 135]. Moreover, recent publications also demonstrated a new mechanism of apoptosis triggered by 1-Nitropyrene and $\mathrm{BaP}$ through lipid accumulation [136], alterations of plasma membrane microstructures, especially modulation of the $\mathrm{Na}^{+} / \mathrm{H}^{+}$exchanger, inhibition of the gap junctional intercellular communication [137], and alteration of lipid rafts' composition [138]. These interesting outcomes emphasize the possible dialogue between plasma membrane alterations and cell death. Impacts on the plasma membrane remodeling might provide additional mechanistic explanations of how some chemicals exert their carcinogenic effect [25].

\section{Cytoprotective Effects of Air Pollutants}

Since mid-twentieth century, the incidence in lung cancer had rapidly increased and, in addition to cigarette smoke, indoor and outdoor air pollution was also questioned through epidemiological studies. The earliest studies underlined the higher incidence of lung cancer in urban versus rural areas, in relation to the nature or concentration of airborne particles. The IARC classified several air pollutants as human carcinogens (group 1, e.g., BaP, Chromium VI compounds, tobacco smoking), probably carcinogens (group 2A, e.g., dibenzo(a,h)anthracene, engine diesel exhaust, lead compounds), possibly carcinogens (group 2B, e.g., benzo(k)fluoranthene, gasoline exhaust, lead), not classifiable as to its carcinogenicity to humans (group 3, e.g., benzo(g,h,i)perylene, chromium III compounds), or probably not carcinogenic to humans (group 4) [9, 139, 140]. In particular, extracts of $\mathrm{PM}, \mathrm{BaP}$, and 1,6-dinitropyrene provoke DNA adducts, mutagenic effects in bacterial and mammalian cells, chromosomal damages, and cell transformation. Most of human cancers are carcinoma derived from epithelial cells, and in the case of lung cancers, the most common are squamous cell carcinoma (epidermoid carcinoma), large cell carcinoma, small cell carcinoma, and adenocarcinoma [141]. All cancerous cells have acquired six capabilities during the multistage process of tumorigenesis: (i) self-sufficiency in growth signals, (ii) insensitivity to growth-inhibitory signals leading to (iii) limitless replicative potential, (iv) evasion to apoptotic cell death, (v) sustained angiogenesis, and (vi) tissue invasion and metastasis [142]. During chronic exposure to air pollutants, acquisition of resistance towards apoptosis might be a significant step of the molecular mechanisms involved in the initiation and promotion of tumors as demonstrated by Teranishi et al. [143]. Unfortunately, too few toxicological studies have investigated this phenomenon of apoptosis resistance induced possibly by air pollutants and have tried to decipher in detail the underlying molecular mechanisms. In order to delineate mechanisms leading to lung cancers due to exposure to cooking oil fumes (COFs) and its main aldehyde component 2,4-decadienal (2,4-DDE), Hung et al. reported that these pollutants promote survival and proliferation of alveolar cancer cells A549 through increased expression of IAP1, IAP2, Survivin, and Cyclin D1 and the concomitant decrease of XIAP, Caspase-3, and p21 level [144].

As described previously, particulate pollutants or their components may induce cytotoxicity following highconcentrations exposure. Ferecatu et al. initiated studies to determine the specific effect of low doses of airborne particles on different bronchial epithelial cells (tumoral, immortalized, and primary cells) regarding induction or reduction of the apoptotic process. The authors demonstrated that $\mathrm{PM}_{2.5}$ are not cytotoxic but rather trigger a resistance to mitochondrial apoptosis towards well-known cell death inducers (calcimycin (A23187), staurosporine, and oligomycin) [145]. The reduction of apoptosis observed after particle exposure is not related to the proinflammatory response and EGF pathway but is mediated by water-soluble as well as organic components such as heavy PAHs. Among all the water-soluble compounds of PM, a possible candidate responsible for the cytoprotective effect is zinc $(\mathrm{Zn})$, already known to inhibit apoptosis and minimize the oxidative stress (e.g., lipid peroxidation) [146]. Zn may protect cells both directly by stabilizing lipids and proteins of cellular and organelles membranes and indirectly via the maintenance of glutathione levels [147]. The protective effect of $\mathrm{Zn}$ was also assigned to the reduction of DNA fragmentation, processing of procaspase-3 [148] and activation of cytoprotective signaling pathways (including Akt, ERK). In addition, some divalent transition metals $\left(\mathrm{Mg}^{2+}, \mathrm{Sr}^{2+}\right.$, and $\mathrm{Mn}^{2+}$ ) can competitively inhibit the calcium-induced PTP opening through a still-unknown mechanism, suggesting a possible direct and protective effect of metallic compounds on mitochondria [149].

Several studies have reported the cytoprotective effects of organic compounds of PM such as PAHs [145, 150] or their metabolites [143, 151], TCDD [152], non-Dioxin-like PCBs [153], and DEP [154]. The exact mechanisms of apoptosis inhibition are not fully understood but in vitro studies have shown the necessity of protein synthesis [155], p53 modulation [153, 156], and AhR activation [145]. Indeed, exposure of human bronchial epithelial cells for 4 hours with different PAHs, prior to A23187-treatment, showed a marked resistance to mitochondria-driven apoptosis only with PAHs containing at least five-aromatic rings, which are the most toxic and potent inducers of receptor Ah (Table 2) [157]. The need of protein synthesis and AhR activation might be linked to the transcription factor function of AhR that could either induce antiapoptotic genes or inhibit proapoptotic ones. This assumption is based on results which have shown 
TABLE 2: The cytoprotective effect of $\mathrm{PM}_{2.5}$ is related to PAHs with five-aromatics rings. Epithelial $16 \mathrm{HBE}$ cells were pretreated during 4 hours with phenanthrene $(124 \mathrm{nM})$, fluoranthene $(268 \mathrm{nM})$, benzo(b)fluoranthene $(333 \mathrm{nM})$, benzo(k)fluoranthene (333 nM), benzo(a)pyrene $(270 \mathrm{nM})$, dibenzo(a,h)anthracene $(35 \mathrm{nM})$, benzo(g,h,i)perylene $(443 \mathrm{nM})$, and indeno(1,2,3-cd)pyrene (217 nM) prior to induction of apoptosis by A23187 $(3 \mu \mathrm{M})$ for 20 supplementary hours. Results are mean \pm SD $(n=6)$. Significance was calculated with Dunnett's test $\left({ }^{*} P<0.01\right.$ versus vehicule cyclohexane $\left.1 \%\right)$. Percentages of DiOC low and PI high refer to cells showing either a drop of $\Delta \Psi \mathrm{m}$ or a permeabilization of the plasma membrane measured using DiOC and propidium iodide (PI) probes, respectively. Note that a $4 \mathrm{~h}$ vehicle pretreatment provides $93.00 \pm 3.31 \%$ DiOC low and $96.97 \pm 7.18 \%$ PI high of A23-induced apoptosis, respectively. Moreover, a 4 h PM 2.5 exposure $\left(10 \mu \mathrm{g} / \mathrm{cm}^{2}\right)$ provides $64.33 \pm 9.89 \%$ DiOC low and $39.45 \pm 8.50 \%$ PI high of A23-induced apoptosis, respectively. The relative toxic potency of individual PAH compared to $\mathrm{BaP}$ is given as the toxic equivalency factor (TEF).

\begin{tabular}{|c|c|c|c|c|}
\hline \multirow{2}{*}{ PAHs } & \multirow{2}{*}{ TEF } & \multirow{2}{*}{ Structure } & \multicolumn{2}{|c|}{ A23187-induced apoptosis (\% of control) } \\
\hline & & & DiOC low & PI high \\
\hline Phenanthrene & $0.001-0.01$ & & $88.96 \pm 5.00$ & $94.43 \pm 6.33$ \\
\hline Fluoranthene & $0.001-0.05$ & & $86.22 \pm 7.13$ & $87.37 \pm 10.79$ \\
\hline Benzo(b)fluoranthene & $0.06-0.14$ & & $91.17 \pm 3.62$ & $99.17 \pm 8.41$ \\
\hline Benzo(k)fluoranthene & $0.03-0.1$ & & $96.41 \pm 6.56$ & $104.09 \pm 11.45$ \\
\hline Benzo(a)pyrene & 1 & & $70.27 \pm 5.60^{*}$ & $34.55 \pm 3.68^{*}$ \\
\hline Dibenzo(a,h)anthracene & $0.69-5$ & & $80.69 \pm 1.26^{*}$ & $80.10 \pm 5.37^{*}$ \\
\hline $\operatorname{Benzo}(g, h, i)$ perylene & $0.01-0.03$ & & $75.49 \pm 2.94^{*}$ & $75.91 \pm 3.31^{*}$ \\
\hline Indeno(1,2,3-cd)pyrene & $0.017-0.232$ & & $79.38 \pm 4.43^{*}$ & $80.24 \pm 10.38^{*}$ \\
\hline
\end{tabular}

that AhR directly interacts with E2F1 leading to the reduction of E2F1-mediated proapoptotic genes such as apaf-1 [158]. Moreover, the cytoprotective effect of AhR ligands is effective at the mitochondrial checkpoint of apoptosis by upregulating expression of antiapoptotic genes such as $b c l-2, b c l-x_{L}, m c l-1$, agr2, or vdac2 [159-161].

Signaling pathways other than AhR were also found in the cytoprotective effects of air pollutants, especially protein kinases (e.g., Akt [162], ERK [163], JNK, PKA [164]), or the transcription factor Nrf2 (nuclear factor (erythroidderived 2)-like 2). PI3K/Akt and AhR pathways seem to be interdependent for the cellular response to xenobiotics, since the presence of $\mathrm{AhR}$ is required for the cytoprotective function of Akt [165]. In addition, the antiapoptotic effect of DEP and BPDE (a BaP genotoxic metabolite) was linked to phosphorylation and activation of Akt [151], with the possible involvement of Thioredoxin-1 as demonstrated in vivo [166]. Furthermore, Akt promotes type II Hexokinase (HK II) phosphorylation and binding to the OM leading to the stabilization of PTP complex in closed conformation and the inhibition of $\mathrm{Ca}^{2+}$-induced Cytochrome $c$ release. Akt-dependent phosphorylation of mitochondrial HK II is further favored when glycogen synthase kinase $3 \beta(\mathrm{GSK} 3 \beta)$ is inactivated by Akt phosphorylation [167]. Finally, activation of NF- $\kappa \mathrm{B}$ and AP- 1 by exposure to airborne PM or cigarette smoke is well documented and admitted as being part of 
inflammatory or proliferative response [168, 169], but their role in the modulation of apoptotic cell death remains unclear.

As recently reviewed, air pollutants are also inductors of Nrf2 which regulates the expression of phase II detoxifying enzymes as well as cytoprotective antioxidants [170]. Under normal conditions, Nrf2 is a cytoplasmic protein linked to its repressor Keap1 (Kelch-like ECH-associated protein) but exposure to low levels of electrophiles and ROS causes the nuclear translocation of $\mathrm{Nrf} 2$ and the subsequent expression of target genes containing antioxidant response elements (ARE). Indeed, numerous published studies have reported activation of Nfr2 after exposure of murine macrophages or human bronchial epithelial cells to DEP, PAHs, and UFP $[81,171,172]$. Among the antiapoptotic target proteins of Nfr2, two antioxidant enzymes are of particular interest because of their location and action on the mitochondria: Heme Oxygenase-1 (HO-1) and Glutathione S-transferase (GST) isoenzymes. Expression and activity of HO-1 are dramatically increased in mitochondrial fractions of human alveolar and bronchial cells exposed to cigarette smoke extract as an attempt to counteract its toxic effects, since the overexpression of HO-1 inhibits cell death and maintains ATP levels [173]. The cytoprotective mechanism of HO-1 involves its enzymatic reaction products such as biliverdin, carbon monoxide (CO), and ferrous iron [174]. In response to $\mathrm{Fe}^{2+}$ production, ferritin protein stability is increased and may protect cells from oxidative and Fas-induced apoptosis. However, biliverdin and free iron do not have any protective activity against oxidative stress-induced hepatic apoptosis, suggesting that CO may be the key molecule [175]. Indeed, $\mathrm{CO}$ protects against oxidative injuries and cell death, since in addition to limiting the translocation of Bcl-2 family proteins to mitochondria and the Cytochrome $c$ release, Queiroga et al. proposed a new cytoprotective effect of CO directly on mitochondria [176]. They observed that a fifteenminutes pretreatment with low doses of $\mathrm{CO}$ was able to prevent the calcium-induced swelling and depolarization of liver isolated mitochondria. Otherwise, GST enzymes are involved in detoxification of endogenous toxic metabolites, superoxide radicals, and xenobiotics. Cytosolic and mitochondrial GST $(\alpha, \mu, \pi$, and $\theta)$ were shown to be upregulated by numerous xenobiotics and some AhR ligands (TCDD, $\beta$-naphthoflavone) [177]. However, effect of mitochondrial GST on the direct control of this organelle is still subject of controversy: on the one hand, these enzymes are assumed to prevent cardiolipin oxidation and MMP [178], while on the other hand, Aniya's team demonstrated that the mitochondrial membrane-bound GST1 is activated by Sglutathionylation and contributes to Cytochrome $c$ release through PTP opening [179].

ROS are possibly involved in tumor progression, metastasis, and multiple signaling pathways elicited by atmospheric xenobiotics. The correlation of intracellular oxidationdue to light-modified derivatives of $\mathrm{BaP}$ (BaP-1,6-dione, BaP-3,6-dione, BaP-4,5-dihydrodiol and 2-hydroxy-BaP-1,6dione)-with the protection against serum withdrawalinduced apoptosis has clearly suggested that a certain dose of ROS enhances cell proliferation and survival [143].

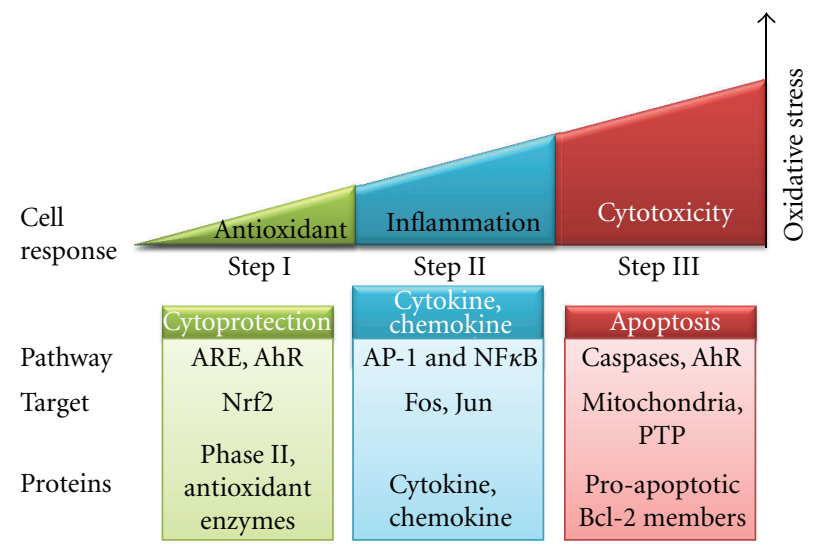

Figure 2: Hierarchical oxidative stress model in response to air pollutants. Low ROS production (Step I) induces activation of cellular antioxidant systems to restore redox homeostasis. If this protection is insufficient, the increased stress (Step II) triggers an inflammatory response through MAPK and NF $\kappa$ B pathways. At a final stage (Step III), all the defense systems are overwhelmed and high ROS levels lead to PTP opening and cell death by apoptosis. These responses depend on the pro/antioxidant balance which varies from one living being to another (adapted from [180]).

Under physiological conditions, cell viability is critically dependent on the maintenance of functional antioxidant systems especially in lung cells which are regularly exposed to air pollutants. GSH is one of the most abundant antioxidant found in the extracellular epithelial lining fluid and into respiratory cells from trachea to alveoli [181]. According to this preponderant role of GSH, administration of antioxidants, such as N-acetylcysteine (NAC), effectively prevents air pollutant-induced apoptosis $[126,171,182]$ and in vivo exposure to dioxin increases levels of mitochondrial glutathione in wt, cyp $1 a 1^{-/-}$and $c y p 1 a 2^{-/-}$mice, but not in ahr ${ }^{-1-}$ mice [83].

\section{Conclusion}

In conclusion, impacts of air pollutants are mainly related to the redox status and the mitochondrial function of target cells. As described in this paper, proteins and signaling pathways involved in both cytoprotective and cytotoxic effects converge to the pro/antioxidant balance which determines the cellular response to environmental aggressions according to the hierarchical model proposed by Li et al. [180] (see Figure 2). Exposure to environmental pollutants may result in cellular disorders responsible for tissue damage and is therefore perceived as a cellular stress. A minor stress will induce a cellular response characterized by metabolic, morphological, or signaling alterations in order to deal with it. This phenomenon, termed adaptation, involves several processes such as hypertrophy, hyperplasia, or atrophy of the cells. Persistent exposures may also result in metaplasia (replacement of one by another cell type as is the case for the ciliated columnar cells that are replaced by squamous cells in the cigarette smokers' epithelium). In case of severe 
injuries, adaptative processes are overwhelmed leading to cell death by necrosis, apoptosis, or autophagy. Air pollutants can directly affect the respiratory epithelium and cause transient damages (i.e., loss of cilia and tight junctions) until total desquamation. Thus, cellular adaptation allows tissue remodeling required for the repair/regeneration of the damaged lung epithelium.

In this context, the cytoprotective effects demonstrated for some xenobiotics might reflect the setting up of an adaptative mechanism converging to the inhibition of cell death deleterious for the lung tissue. However, as it was well described by Barouki [183], some adaptative mechanisms necessary to inhibit direct toxicity may have side effects that accumulate during repeated exposures. A plausible assumption for the exacerbation of lung cancers would be that resistance to apoptosis might occur into self-renewing stem cells known to be involved in physiological regeneration of the epithelium and suspected of being initiators of lung tumors [13].

Despite the latest significant advances, the specific mechanisms responsible for cytotoxic effects of air pollutants remain to be deciphered in more detail, mostly on the issues of chronic as well as multiple exposures to low concentrations of pollutants. Moreover, understanding the adaptive cytoprotective process is an important issue that should be considered in the risk assessment of air pollution.

\section{Abbreviations}

2,4-DDE: 2,4-decadienal

8-OHdG: 8-hydroxy-2'-desoxyguanosine

A23187: Calcium ionophore (calcimycin)

AFSSET: French Agency of Environmental and Occupational Health Safety

AhR: Aryl hydrocarbon receptor

AIF: Apoptosis-inducing factor

ANT: Adenine nucleotide translocator

Apaf-1: Apoptosis protease activating factor 1

ARE: Antioxidant response elements

As: $\quad$ Arsenic

BaP: Benzo(a)pyrene

BPDE: anti-7,8-dihydrodiol-9,10-epoxybenzo(a)pyrene4

CAD: Caspase-activated DNase

Cd: Cadmium

CFCs: Chlorofluorocarbons

$\mathrm{CH}_{4}$ : Methane

CO: $\quad$ Carbon monoxide

Co: Cobalt

$\mathrm{CO}_{2}$ : Carbon dioxide

COF: Cooking oil fumes

COPD: Chronic obstructive pulmonary disease

Cr: Chromium

CsA: Cyclosporine A

Cu: Copper

DEP: Diesel exhaust particles

DIDS: 4,4-diisothiocyanatostilbene-

$2,2^{\prime}$ disulfonic acid
DiOC: 3, 3 dihexyloxacarbocyanine iodide

DISC: Death-inducing signalling complex

DNP: 2,4-dinitrophenol

EGFR: Epidermal growth factor receptor

EndoG: Endonuclease G

EPA: Environmental Protection Agency

FAD: $\quad$ Flavin adenine dinucleotide

FADD: Fas-associated protein with death domain

FP: $\quad$ Fine particles

GSH: $\quad$ L- $\gamma$-glutamyl-L-cysteinylglycine

GSK3 $\beta$ : Glycogen synthase kinase $3 \beta$

GST: $\quad$ Glutathione S-transferase

$\mathrm{H}_{2} \mathrm{O}_{2}$ : Hydrogen peroxide

$\mathrm{H}_{2} \mathrm{~S}$ : Hydrogen sulfide

Hg: $\quad$ Mercury

HK II: Hexokinase type II

$\mathrm{HO}^{\bullet}$ : Hydroxyl radical

HO-1: Heme oxygenase-1

IAP1: Inhibitors of apoptosis

IARC: International Agency for Research on

Cancer

IM: Mitochondrial inner membrane

IMS: Mitochondrial intermembrane space

Keap1: Kelch-like ECH-associated protein

MMP: Mitochondrial membranes permeabilization

mtDNA: Mitochondrial DNA

$\mathrm{N}_{2} \mathrm{O}: \quad$ Nitrous oxide

NAAQS: National Ambient Air Quality Standards

NAC: $\quad$ N-acetylcysteine

Ni: $\quad$ Nickel

NO: $\quad$ Nitrogen monoxide

$\mathrm{NO}_{2}$ : $\quad$ Nitrogen dioxide

NOx: Nitrogen oxides

NP: $\quad$ Nanoparticles

NQO1: NADPH : quinone oxidoreductase

Nrf2: $\quad$ Nuclear factor (erythroid-derived 2)-like 2

$\mathrm{O}_{2}{ }^{\bullet-}$ : $\quad$ Superoxide anion

$\mathrm{O}_{3}$ : $\quad$ Ozone

OM: $\quad$ Mitochondrial outer membrane

OXPHOS: Oxidative phosphorylations

PAHs: Polycyclic aromatic hydrocarbons

PARP-1: Poly (ADP-ribose) polymerase 1

Pb: $\quad$ Lead

PCBs: $\quad$ Polychlorinated biphenyls

PCDDs: Polychlorinated dibenzo-p-dioxins

PCDFs: Polychlorinated dibenzofurans

PI: $\quad$ Propidium iodide

PM: $\quad$ Particulate matter

ppb: $\quad$ parts per billion

ppm: $\quad$ Parts per million

PTP: $\quad$ Permeability transition pore complex

ROS: $\quad$ Reactive oxygen species

Sb: Antimony

Se: Selenium

$\mathrm{SO}_{2}$ : $\quad$ Sulfur dioxide

SOD: $\quad$ Mn-superoxide dismutase

TCDD: 2,3,7,8-tetrachlorodibenzo-p-dioxin

TEF: Toxic equivalency factor 
TNFR: Tumour necrosis factor receptor

TRADD: TNF-receptor-associated death domain protein

TSPO: Translocator protein

UFP: Ultrafine particles

$\mathrm{V}$ : $\quad$ Vanadium

VDAC: Voltage-dependent anion channel

VOC: Volatile organic compounds

XIAP: X-linked inhibitor of apoptosis protein

Zn: $\quad$ Zinc

$\Delta \Psi \mathrm{m}: \quad$ Mitochondrial transmembrane potential.

\section{Acknowledgments}

Support for this paper was from the French Agence Nationale de la Recherche (ANR), Centre National de la Recherche Scientifique (CNRS), Université Paris Diderot-Paris 7 (Ph.D. grant of Mélanie Leroux), Région Ile de France, and DIM SEnT (postdoctoral grant of Aïda Bouharrour). The authors particularly thank Dr. Christophe Lemaire, Dr. Ioana Ferecatu, and Dr. Armelle Baeza-Squiban for their critical reading of the paper.

\section{References}

[1] C. A. Pope III, R. T. Burnett, M. J. Thun et al., "Lung cancer, cardiopulmonary mortality, and long-term exposure to fine particulate air pollution," JAMA, vol. 287, no. 9, pp. 11321141, 2002.

[2] J. Lewtas, "Air pollution combustion emissions: characterization of causative agents and mechanisms associated with cancer, reproductive, and cardiovascular effects," Mutation Research, vol. 636, no. 1-3, pp. 95-133, 2007.

[3] P. Borm and K. K. Donaldson, "An Introduction to Particle Toxicology; from coal mining to nanotechnology," in Particle Toxicology, P. Borm and K. K. Donaldson, Eds., pp. 1-12, CRC Press, 2007.

[4] B. Ostro et al., The Effects of Particulate Matter Sources on Daily Mortality: A Case-Crossover Study of Barcelona, Environ Health Perspect, Barcelona, Spain, 2011.

[5] G. Oberdörster, E. Oberdörster, and J. Oberdörster, "Nanotoxicology: an emerging discipline evolving from studies of ultrafine particles," Environmental Health Perspectives, vol. 113, no. 7, pp. 823-839, 2005.

[6] T. Jones and K. Bérubé, "Mineralogy an structure of pathogenic particles," in Particle Toxicology, P. Borm and K. K. Donaldson, Eds., pp. 13-45, CRC Press, 2007.

[7] F. Marano, S. Boland, V. Bonvallot, A. Baulig, and A. Baeza-Squiban, "Human airway epithelial cells in culture for studying the molecular mechanisms of the inflammatory response triggered by diesel exhaust particles," Cell Biology and Toxicology, vol. 18, no. 5, pp. 315-320, 2002.

[8] W. Roemer, G. Hoek, and B. Brunekreef, "Effect of ambient winter air pollution on respiratory health of children with chronic respiratory symptoms," American Review of Respiratory Disease, vol. 147, no. 1, pp. 118-124, 1993.

[9] International Agency for Research on Cancer (IARC), http://www.iarc.fr/.

[10] P. Boffetta, S. D. Stellman, and L. Garfinkel, "Diesel exhaust exposure and mortality among males in the American Cancer
Society prospective study," American Journal of Industrial Medicine, vol. 14, no. 4, pp. 403-415, 1988.

[11] French Agency of Environmental and Occupational Health Safety (AFSSET), "Estimation de l'impact lié à l'exposition chronique aux particules fines sur l'espérance de vie," in Impact Sanitaire de la Pollution Atmosphérique Urbaine, 2005.

[12] "Particulate air pollutants and small airway remodeling," in Particle Toxicology, A. Churg, Ed.P. Borm and K. K. Donaldson, Eds., pp. 75-87, CRC Press, 2007.

[13] J. P. Sullivan, J. D. Minna, and J. W. Shay, "Evidence for selfrenewing lung cancer stem cells and their implications in tumor initiation, progression, and targeted therapy," Cancer and Metastasis Reviews, vol. 29, no. 1, pp. 61-72, 2010.

[14] Environmental Protection Agency (EPA), http://epa.gov/ air/criteria.html.

[15] Centre Interprofesionnel Technique d'Etudes de la Pollution Atmosphérique (CITEPA), http://www.citepa.org/pollution/ sources.htm.

[16] "Sources of air pollution," in Air Pollution and Health, C. Holman, Ed.S. T. Holgate et al., Ed., pp. 115-148, Academic Press, 1999.

[17] S. Orrenius, P. Nicotera, and B. Zhivotovsky, "Cell death mechanisms and their implications in toxicology," Toxicological Sciences, vol. 119, no. 1, pp. 3-19, 2011.

[18] D. K. Dhawan and V. D. Chadha, "Zinc: a promising agent in dietary chemoprevention of cancer," Indian Journal of Medical Research, vol. 132, no. 12, pp. 676-682, 2010.

[19] G. Gobe and D. Crane, "Mitochondria, reactive oxygen species and cadmium toxicity in the kidney," Toxicology Letters, vol. 198, no. 1, pp. 49-55, 2010.

[20] J. M. Matés, J. A. Segura, F. J. Alonso, and J. Márquez, "Roles of dioxins and heavy metals in cancer and neurological diseases using ROS-mediated mechanisms," Free Radical Biology and Medicine, vol. 49, no. 9, pp. 1328-1341, 2010.

[21] H. T. Chung, B. M. Choi, Y. G. Kwon, and Y. M. Kim, "Interactive relations between nitric oxide $(\mathrm{NO})$ and carbon monoxide (CO): heme oxygenase-1/CO pathway is a key modulator in NO-mediated antiapoptosis and antiinflammation," Methods in Enzymology, vol. 441, pp. 329338, 2008.

[22] M. C. Ferrante, G. Mattace Raso, E. Esposito et al., "Effects of non-dioxin-like polychlorinated biphenyl congeners (PCB 101, PCB 153 and PCB 180) alone or mixed on J774A.1 macrophage cell line: modification of apoptotic pathway," Toxicology Letters, vol. 202, no. 1, pp. 61-68, 2011.

[23] G. Kroemer, L. Galluzzi, P. Vandenabeele et al., "Classification of cell death: recommendations of the nomenclature committee on cell death 2009," Cell Death and Differentiation, vol. 16, no. 1, pp. 3-11, 2009.

[24] D. Wlodkowic, W. Telford, J. Skommer, and Z. Darzynkiewicz, "Apoptosis and beyond: cytometry in studies of programmed cell death," Methods in Cell Biology, vol. 103, pp. 55-98, 2011.

[25] X. Tekpli, J. A. Holme, O. Sergent, and D. Lagadic-Gossmann, "Importance of plasma membrane dynamics in chemicalinduced carcinogenesis," Recent Patents on Anti-Cancer Drug Discovery, vol. 6, no. 3, pp. 347-353, 2011.

[26] D. Chen, R. A. Stetler, G. Cao et al., "Characterization of the rat DNA fragmentation factor 35/inhibitor of caspaseactivated DNase (short form): the endogenous inhibitor of caspase-dependent DNA fragmentation in neuronal 
apoptosis," The Journal of Biological Chemistry, vol. 275, no. 49, pp. 38508-38517, 2000.

[27] Y. Ishihara and N. Shimamoto, "Involvement of endonuclease G in nucleosomal DNA fragmentation under sustained endogenous oxidative stress," The Journal of Biological Chemistry, vol. 281, no. 10, pp. 6726-6733, 2006.

[28] Y. Harihara, K. Sanjo, and Y. Idezuki, "A modified cuff technique for suprahepatic vena cava anastomosis in rat liver transplantation," Transplantation, vol. 53, no. 3, pp. 707-709, 1992.

[29] E. Norberg, S. Orrenius, and B. Zhivotovsky, "Mitochondrial regulation of cell death: processing of apoptosis-inducing factor (AIF)," Biochemical and Biophysical Research Communications, vol. 396, no. 1, pp. 95-100, 2010.

[30] T.-J. Fan, L.-H. Han, R.-S. Cong, and J. Liang, "Caspase family proteases and apoptosis," Acta Biochimica et Biophysica Sinica, vol. 37, no. 11, pp. 719-727, 2005.

[31] F. Q. Alenzi, M. Lotfy, and R. K. Wyse, "Swords of cell death: caspase activation and regulation," Asian Pacific Journal of Cancer Prevention, vol. 11, no. 2, pp. 271-280, 2010.

[32] M. Paulsen and O. Janssen, "Pro- and anti-apoptotic CD95 signaling in T cells," Cell Communication and Signaling, vol. 9, article 7, 2011.

[33] G. Kroemer, L. Galluzzi, and C. Brenner, "Mitochondrial membrane permeabilization in cell death," Physiological Reviews, vol. 87, no. 1, pp. 99-163, 2007.

[34] L. Galluzzi, N. Zamzami, T. De La Motte Rouge, C. Lemaire, C. Brenner, and G. Kroemer, "Methods for the assessment of mitochondrial membrane permeabilization in apoptosis," Apoptosis, vol. 12, no. 5, pp. 803-813, 2007.

[35] O. Sharaf El Dein, C. Gallerne, A. Deniaud, C. Brenner, and C. Lemaire, "Role of the permeability transition pore complex in lethal inter-organelle crosstalk," Frontiers in Bioscience, vol. 14, pp. 3465-3482, 2009.

[36] V. Shoshan-Barmatz and D. Ben-Hail, "VDAC, a multifunctional mitochondrial protein as a pharmacological target," Mitochondrion, vol. 12, no. 1, pp. 24-34, 2012.

[37] F. Verrier, B. Mignotte, G. Jan, and C. Brenner, "Study of PTPC composition during apoptosis for identification of viral protein target," Annals of the New York Academy of Sciences, vol. 1010, pp. 126-142, 2003.

[38] F. Verrier, A. Deniaud, M. LeBras et al., "Dynamic evolution of the adenine nucleotide translocase interactome during chemotherapy-induced apoptosis," Oncogene, vol. 23, no. 49, pp. 8049-8064, 2004.

[39] G. P. McStay, S. J. Clarke, and A. P. Halestrap, "Role of critical thiol groups on the matrix surface of the adenine nucleotide translocase in the mechanism of the mitochondrial permeability transition pore," Biochemical Journal, vol. 367, no. 2, pp. 541-548, 2002.

[40] P. Costantini, A. S. Belzacq, H. L. A. Vieira et al., "Oxidation of a critical thiol residue of the adenine nucleotide translocator enforces Bcl-2-independent permeability transition pore opening and apoptosis," Oncogene, vol. 19, no. 2, pp. 307$314,2000$.

[41] A. Philchenkov, M. Zavelevich, T. J. Kroczak, and M. Los, "Caspases and cancer: mechanisms of inactivation and new treatment modalities," Experimental Oncology, vol. 26, no. 2, pp. 82-97, 2004.

[42] G. Martinez-Ruiz, V. Maldonado, G. Ceballos-Cancino, J. P. R. Grajeda, and J. Melendez-Zajgla, "Role of Smac/DIABLO in cancer progression," Journal of Experimental and Clinical Cancer Research, vol. 27, no. 1, article 48, 2008.

[43] D. Acehan, X. Jiang, D. G. Morgan, J. E. Heuser, X. Wang, and C. W. Akey, "Three-dimensional structure of the apoptosome: implications for assembly, procaspase-9 binding, and activation," Molecular Cell, vol. 9, no. 2, pp. 423-432, 2002.

[44] T. F. Reubold, S. Wohlgemuth, and S. Eschenburg, "A new model for the transition of APAF-1 from inactive monomer to caspase-activating apoptosome," The Journal of Biological Chemistry, vol. 284, no. 47, pp. 32717-32724, 2009.

[45] S. Qi, Y. Pang, Q. Hu et al., "Crystal structure of the caenorhabditis elegans apoptosome reveals an octameric assembly of CED-4," Cell, vol. 141, no. 3, pp. 446-457, 2010.

[46] X. Teng and J. M. Hardwick, "The apoptosome at high resolution," Cell, vol. 141, no. 3, pp. 402-404, 2010.

[47] K. Andreau, M. Castedo, J. L. Perfettini et al., "Preapoptotic chromatin condensation upstream of the mitochondrial checkpoint," The Journal of Biological Chemistry, vol. 279, no. 53, pp. 55937-55945, 2004.

[48] A. Strasser, S. Cory, and J. M. Adams, "Deciphering the rules of programmed cell death to improve therapy of cancer and other diseases," The EMBO Journal, vol. 30, no. 18, pp. 36673683, 2011.

[49] Y. Hu, M. A. Benedict, D. Wu, N. Inohara, and G. Núñez, "Bcl-XL interacts with Apaf-1 and inhibits Apaf-1-dependent caspase-9 activation," Proceedings of the National Academy of Sciences of the United States of America, vol. 95, no. 8, pp. 4386-4391, 1998.

[50] G. Pan, K. O’Rourke, and V. M. Dixit, "Caspase-9, Bcl-X(L), and Apaf-1 form a ternary complex," The Journal of Biological Chemistry, vol. 273, no. 10, pp. 5841-5845, 1998.

[51] S. Conus, T. Rosse, and C. Borner, "Failure of Bcl-2 family members to interact with Apaf-1 in normal and apoptotic cells," Cell Death and Differentiation, vol. 7, no. 10, pp. 947954, 2000.

[52] G. Hausmann, L. A. O'Reilly, R. Van Driel et al., "Proapoptotic apoptosis protease-activating factor 1 (Apaf-1) has a cytoplasmic localization distinct from Bcl-2 or Bcl-x(L)," Journal of Cell Biology, vol. 149, no. 3, pp. 623-633, 2000.

[53] S. Shimizu, Y. Eguchi, W. Kamiike et al., "Bcl-2 prevents apoptotic mitochondrial dysfunction by regulating proton flux," Proceedings of the National Academy of Sciences of the United States of America, vol. 95, no. 4, pp. 1455-1459, 1998.

[54] M. G. Vander Heiden, N. S. Chandel, P. T. Schumacker, and C. B. Thompson, "Bcl-x(L) prevents cell death following growth factor withdrawal by facilitating mitochondrial ATP/ADP exchange," Molecular Cell, vol. 3, no. 2, pp. 159$167,1999$.

[55] M. Wierzbicka, "Morphology of gingival epithelium in the light of modern research," Czasopismo Stomatologiczne, vol. 28, no. 10, pp. 969-972, 1975.

[56] I. Al Ghouleh, N. K. H. Khoo, U. G. Knaus et al., "Oxidases and peroxidases in cardiovascular and lung disease: new concepts in reactive oxygen species signaling," Free Radical Biology and Medicine, vol. 51, no. 7, pp. 1271-1288, 2011.

[57] V. C. Fogg, N. J. Lanning, and J. P. MacKeigan, "Mitochondria in cancer: at the crossroads of life and death," Chinese Journal of Cancer, vol. 30, no. 8, pp. 526-539, 2011.

[58] E. Cadenas and K. J. A. Davies, "Mitochondrial free radical generation, oxidative stress, and aging," Free Radical Biology and Medicine, vol. 29, no. 3-4, pp. 222-230, 2000.

[59] S. Macip, M. Igarashi, P. Berggren, J. Yu, S. W. Lee, and S. A. Aaronson, "Influence of induced reactive oxygen species 
in p53-mediated cell fate decisions," Molecular and Cellular Biology, vol. 23, no. 23, pp. 8576-8585, 2003.

[60] S.-Y. Ho, W. Wu Jr., H.-W. Chiu et al., "Arsenic trioxide and radiation enhance apoptotic effects in HL-60 cells through increased ROS generation and regulation of JNK and p38 MAPK signaling pathways," Chemico-Biological Interactions, vol. 193, no. 2, pp. 162-171, 2011.

[61] B. M. Emerling, L. C. Platanias, E. Black, A. R. Nebreda, R. J. Davis, and N. S. Chandel, "Mitochondrial reactive oxygen species activation of p38 mitogen-activated protein kinase is required for hypoxia signaling," Molecular and Cellular Biology, vol. 25, no. 12, pp. 4853-4862, 2005.

[62] A. J. Kowaltowski, R. F. Castilho, and A. E. Vercesi, "Opening of the mitochondrial permeability transition pore by uncoupling or inorganic phosphate in the presence of $\mathrm{Ca} 2+$ is dependent on mitochondrial-generated reactive oxygen species," FEBS Letters, vol. 378, no. 2, pp. 150-152, 1996.

[63] G. Paradies, G. Petrosillo, M. Pistolese, and F. M. Ruggiero, "The effect of reactive oxygen species generated from the mitochondrial electron transport chain on the cytochrome c oxidase activity and on the cardiolipin content in bovine heart submitochondrial particles," FEBS Letters, vol. 466, no. 2-3, pp. 323-326, 2000.

[64] S. Orrenius, V. Gogvadze, and B. Zhivotovsky, "Mitochondrial oxidative stress: implications for cell death," Annual Review of Pharmacology and Toxicology, vol. 47, pp. 143-183, 2007.

[65] T. R. Pushpa-Rekha, A. L. Burdsall, L. M. Oleksa, G. M. Chisolm, and D. M. Driscoll, "Rat phospholipidhydroperoxide glutathione peroxidase. cDNA cloning and identification of multiple transcription and translation start sites," The Journal of Biological Chemistry, vol. 270, no. 45, pp. 26993-26999, 1995.

[66] J. Legault, C. Carrier, P. Petrov, P. Renard, J. Remacle, and M. E. Mirault, "Mitochondrial GPx1 decreases induced but not basal oxidative damage to mtDNA in T47D cells," Biochemical and Biophysical Research Communications, vol. 272, no. 2, pp. 416-422, 2000.

[67] M. Lundberg, C. Johansson, J. Chandra et al., "Cloning and expression of a novel human glutaredoxin (Grx2) with mitochondrial and nuclear isoforms," The Journal of Biological Chemistry, vol. 276, no. 28, pp. 26269-26275, 2001.

[68] H. Wu, K. Xing, and M. F. Lou, "Glutaredoxin 2 prevents $\mathrm{H} 2 \mathrm{O} 2$-induced cell apoptosis by protecting complex I activity in the mitochondria," Biochimica et Biophysica Acta, vol. 1797, no. 10, pp. 1705-1715, 2010.

[69] Y. Aniya and N. Imaizumi, "Mitochondrial glutathione transferases involving a new function for membrane permeability transition pore regulation," Drug Metabolism Reviews, vol. 43, no. 2, pp. 292-299, 2011.

[70] J. Zhang, A. J. Ghio, W. Chang, O. Kamdar, G. D. Rosen, and D. Upadhyay, "Bim mediates mitochondria-regulated particulate matter-induced apoptosis in alveolar epithelial cells," FEBS Letters, vol. 581, no. 22, pp. 4148-4152, 2007.

[71] W. Y. Wani, S. Gudup, A. Sunkaria et al., "Protective efficacy of mitochondrial targeted antioxidant MitoQ against dichlorvos induced oxidative stress and cell death in rat brain," Neuropharmacology, vol. 61, no. 8, pp. 1193-1201, 2011.

[72] R. Franco, R. Sánchez-Olea, E. M. Reyes-Reyes, and M. I. Panayiotidis, "Environmental toxicity, oxidative stress and apoptosis: menage a trois," Mutation Research, vol. 674, no. 1-2, pp. 3-22, 2009.
[73] V. N. Samartsev, O. V. Markova, I. P. Zeldi, and A. V. Smirnov, "Role of the ADP/ATP and aspartate/glutamate antiporters in the uncoupling effect of fatty acids, lauryl sulfate, and 2, 4dinitrophenol in liver mitochondria," Biochemistry, vol. 64, no. 8, pp. 901-911, 1999.

[74] M. Gualtieri, P. Mantecca, F. Cetta, and M. Camatini, "Organic compounds in tire particle induce reactive oxygen species and heat-shock proteins in the human alveolar cell line A549," Environment International, vol. 34, no. 4, pp. 437442, 2008.

[75] F. Farina, G. Sancini, P. Mantecca, D. Gallinotti, M. Camatini, and P. Palestini, "The acute toxic effects of particulate matter in mouse lung are related to size and season of collection," Toxicology Letters, vol. 202, no. 3, pp. 209-217, 2011.

[76] E. Alfaro-Moreno, L. Martínez, C. García-Cuellar et al., "Biologic effects induced in vitro by PM10 from three different zones of Mexico City," Environmental Health Perspectives, vol. 110, no. 7, pp. 715-720, 2002.

[77] J. H. Choi, J. S. Kim, Y. C. Kim, Y. S. Kim, N. H. Chung, and M. H. Cho, "Comparative study of PM2.5- and PM10induced oxidative stress in rat lung epithelial cells," Journal of Veterinary Science, vol. 5, no. 1, pp. 11-18, 2004.

[78] O. Kamdar, W. Le, J. Zhang, A. J. Ghio, G. D. Rosen, and D. Upadhyay, "Air pollution induces enhanced mitochondrial oxidative stress in cystic fibrosis airway epithelium," FEBS Letters, vol. 582, no. 25-26, pp. 3601-3606, 2008.

[79] G. Garçon, Z. Dagher, F. Zerimech et al., "Dunkerque City air pollution particulate matter-induced cytotoxicity, oxidative stress and inflammation in human epithelial lung cells (L132) in culture," Toxicology in Vitro, vol. 20, no. 4, pp. 519-528, 2006.

[80] Z. Dagher, G. Garçon, S. Billet et al., "Role of nuclear factorkappa B activation in the adverse effects induced by air pollution particulate matter (PM2.5) in human epithelial lung cells (L132) in culture," Journal of Applied Toxicology, vol. 27, no. 3, pp. 284-290, 2007.

[81] A. Baulig, M. Garlatti, V. Bonvallot et al., "Involvement of reactive oxygen species in the metabolic pathways triggered by diesel exhaust particles in human airway epithelial cells," American Journal of Physiology, vol. 285, no. 3, pp. L671L679, 2003.

[82] M. Lodovici and E. Bigagli, "Oxidative stress and air pollution exposure," Journal of Toxicology, vol. 2011, Article ID 487074, 9 pages, 2011.

[83] A. P. Senft, T. P. Dalton, D. W. Nebert et al., "Mitochondrial reactive oxygen production is dependent on the aromatic hydrocarbon receptor," Free Radical Biology and Medicine, vol. 33, no. 9, pp. 1268-1278, 2002.

[84] T. Xia, P. Korge, J. N. Weiss et al., "Quinones and aromatic chemical compounds in particulate matter induce mitochondrial dysfunction: implications for ultrafine particle toxicity," Environmental Health Perspectives, vol. 112, no. 14, pp. 13471358, 2004.

[85] A. Baeza-Squiban, V. Bonvallot, S. Boland, and F. Marano, "Airborne particles evoke an inflammatory response in human airway epithelium. Activation of transcription factors," Cell Biology and Toxicology, vol. 15, no. 6, pp. 375-380, 1999.

[86] D. Upadhyay, V. Panduri, A. Ghio, and D. W. Kamp, "Particulate matter induces alveolar epithelial cell DNA damage and apoptosis role of free radicals and the mitochondria," American Journal of Respiratory Cell and Molecular Biology, vol. 29, no. 2, pp. 180-187, 2003. 
[87] C. J. Obot, M. T. Morandi, T. P. Beebe, R. F. Hamilton, and A. Holian, "Surface components of airborne particulate matter induce macrophage apoptosis through scavenger receptors," Toxicology and Applied Pharmacology, vol. 184, no. 2, pp. 98 106, 2002.

[88] H. Andersson, E. Piras, J. Demma, B. Hellman, and E. Brittebo, "Low levels of the air pollutant 1-nitropyrene induce DNA damage, increased levels of reactive oxygen species and endoplasmic reticulum stress in human endothelial cells," Toxicology, vol. 262, no. 1, pp. 57-64, 2009.

[89] N. Asare, X. Tekpli, M. Rissel et al., "Signalling pathways involved in 1-nitropyrene (1-NP)-induced and 3nitrofluoranthene (3-NF)-induced cell death in Hepalc1c7 cells," Mutagenesis, vol. 24, no. 6, pp. 481-493, 2009.

[90] K. Chramostová, J. Vondráček, L. Šindlerová, B. Vojtěšek, A. Kozubík, and M. Machala, "Polycyclic aromatic hydrocarbons modulate cell proliferation in rat hepatic epithelial stem-like WB-F344 cells," Toxicology and Applied Pharmacology, vol. 196, no. 1, pp. 136-148, 2004.

[91] J. Van Grevenynghe, L. Sparfel, M. L. Vee et al., "Cytochrome P450-dependent toxicity of environmental polycyclic aromatic hydrocarbons towards human macrophages," Biochemical and Biophysical Research Communications, vol. 317, no. 3, pp. 708-716, 2004.

[92] E. Hrubá, L. Trilecová, S. Marvanová et al., "Genotoxic polycyclic aromatic hydrocarbons fail to induce the p53dependent DNA damage response, apoptosis or cell-cycle arrest in human prostate carcinoma LNCaP cells," Toxicology Letters, vol. 197, no. 3, pp. 227-235, 2010.

[93] R. Barouki and Y. Morel, "Repression of cytochrome P450 1A1 gene expression by oxidative stress: mechanisms and biological implications," Biochemical Pharmacology, vol. 61, no. 5, pp. 511-516, 2001.

[94] E. Hodgson, "Phase 1 metabolism of toxicants and metabolic interactions," in Molecular and Biochemical Toxicology, R. C. Smart and E. Hodgson, Eds., pp. 173-203, John Wiley \& Sons, 4th edition, 2008.

[95] A. H. Conney, R. L. Chang, D. M. Jerina, and S. J. C. Wei, "Studies on the metabolism of benzo[a]pyrene and dosedependent differences in the mutagenic profile of its ultimate carcinogenic metabolite," Drug Metabolism Reviews, vol. 26, no. 1-2, pp. 125-163, 1994.

[96] A. G. Smith, B. Clothier, S. Robinson et al., "Interaction between iron metabolism and 2,3,7,8-tetrachlorodibenzo-pdioxin in mice with variants of the Ahr gene: a hepatic oxidative mechanism," Molecular Pharmacology, vol. 53, no. 1, pp. 52-61, 1998.

[97] A. Cuypers, M. Plusquin, T. Remans et al., "Cadmium stress: an oxidative challenge," BioMetals, vol. 23, no. 5, pp. 927-940, 2010.

[98] X. Wang, Y.-O. Son, Q. Chang et al., "NADPH oxidase activation is required in reactive oxygen species generation and cell transformation induced by hexavalent chromium," Toxicological Sciences, vol. 123, no. 2, pp. 399-410, 2011.

[99] D. B. Buchwalter, "Metals," in Molecular and Biochemical Toxicology, R. C. Smart and E. Hodgson, Eds., pp. 413-439, John Wiley \& Sons, 2008.

[100] M. D. Pulido and A. R. Parrish, "Metal-induced apoptosis: mechanisms," Mutation Research, vol. 533, no. 1-2, pp. 227241, 2003.

[101] D. Beyersmann and A. Hartwig, "Carcinogenic metal compounds: recent insight into molecular and cellular mechanisms," Archives of Toxicology, vol. 82, no. 8, pp. 493-512, 2008.
[102] S. V. S. Rana, "Metals and apoptosis: recent developments," Journal of Trace Elements in Medicine and Biology, vol. 22, no. 4, pp. 262-284, 2008.

[103] J. J. Li, Q. Tang, Y. Li et al., "Role of oxidative stress in the apoptosis of hepatocellular carcinoma induced by combination of arsenic trioxide and ascorbic acid," Acta Pharmacologica Sinica, vol. 27, no. 8, pp. 1078-1084, 2006.

[104] J. P. Bebear, V. Calas, and B. Lablache Combier, "Carbocysteine in catarrhal ORL diseases," Revue de LaryngologieOtologie-Rhinologie, vol. 111, no. 5, pp. 499-501, 1990.

[105] M. Li, T. Xia, C. S. Jiang, L. J. Li, J. L. Fu, and Z. C. Zhou, "Cadmium directly induced the opening of membrane permeability pore of mitochondria which possibly involved in cadmium-triggered apoptosis," Toxicology, vol. 194, no. 12, pp. 19-33, 2003.

[106] J. Ye, S. Wang, S. S. Leonard et al., "Role of reactive oxygen species and $\mathrm{p} 53$ in chromium(VI)-induced apoptosis," The Journal of Biological Chemistry, vol. 274, no. 49, pp. 3497434980, 1999.

[107] P. Russo, A. Catassi, A. Cesario et al., "Molecular mechanisms of hexavalent chromium-induced apoptosis in human bronchoalveolar cells," American Journal of Respiratory Cell and Molecular Biology, vol. 33, no. 6, pp. 589-600, 2005.

[108] R. Zhao, N. Xiang, F. E. Domann, and W. Zhong, "Expression of p53 enhances selenite-induced superoxide production and apoptosis in human prostate cancer cells," Cancer Research, vol. 66, no. 4, pp. 2296-2304, 2006.

[109] K. Donaldson, V. Stone, P. J. A. Borm et al., "Oxidative stress and calcium signaling in the adverse effects of environmental particles (PM10)," Free Radical Biology and Medicine, vol. 34, no. 11, pp. 1369-1382, 2003.

[110] J. Araya, M. Maruyama, A. Inoue et al., "Inhibition of proteasome activity is involved in cobalt-induced apoptosis of human alveolar macrophages," American Journal of Physiology, vol. 283, no. 4, pp. L849-L858, 2002.

[111] H. Geng, Z. Meng, and Q. Zhang, "In vitro responses of rat alveolar macrophages to particle suspensions and watersoluble components of dust storm PM2.5," Toxicology in Vitro, vol. 20, no. 5, pp. 575-584, 2006.

[112] D. W. Kamp, V. Panduri, S. A. Weitzman, and N. Chandel, "Asbestos-induced alveolar epithelial cell apoptosis: role of mitochondrial dysfunction caused by iron-derived free radicals," Molecular and Cellular Biochemistry, vol. 234-235, pp. 153-160, 2002.

[113] M. Jiménez Del Río and C. Vélez-Pardo, "Transition metalinduced apoptosis in lymphocytes via hydroxyl radical generation, mitochondria dysfunction, and caspase-3 activation: an in vitro model for neurodegeneration," Archives of Medical Research, vol. 35, no. 3, pp. 185-193, 2004.

[114] M. Provinciali, A. Donnini, K. Argentati, G. Di Stasio, B. Bartozzi, and G. Bernardini, "Reactive oxygen species modulate $\mathrm{Zn}^{2+}$-induced apoptosis in cancer cells," Free Radical Biology and Medicine, vol. 32, no. 5, pp. 431-445, 2002.

[115] Y. Cho, S. Gorina, P. D. Jeffrey, and N. P. Pavletich, "Crystal structure of a p53 tumor suppressor-DNA complex: understanding tumorigenic mutations," Science, vol. 265, no. 5170, pp. 346-355, 1994.

[116] M. Madesh and G. Hajnóczky, "VDAC-dependent permeabilization of the outer mitochondrial membrane by superoxide induces rapid and massive cytochrome c release," Journal of Cell Biology, vol. 155, no. 6, pp. 1003-1015, 2001.

[117] T. S. Hiura, N. Li, R. Kaplan, M. Horwitz, J. C. Seagrave, and A. E. Nel, "The role of a mitochondrial pathway in the 
induction of apoptosis by chemicals extracted from diesel exhaust particles," Journal of Immunology, vol. 165, no. 5, pp. 2703-2711, 2000.

[118] V. A. Tyurin, Y. Y. Tyurina, M.-Y. Jung et al., "Massspectrometric analysis of hydroperoxy- and hydroxyderivatives of cardiolipin and phosphatidylserine in cells and tissues induced by pro-apoptotic and pro-inflammatory stimuli," Journal of Chromatography B, vol. 877, no. 26, pp. 2863-2872, 2009.

[119] D. Shen, T. P. Dalton, D. W. Nebert, and H. G. Shertzer, "Glutathione redox state regulates mitochondrial reactive oxygen production," The Journal of Biological Chemistry, vol. 280, no. 27, pp. 25305-25312, 2005.

[120] S. C. Chen, T. L. Liao, Y. H. Wei, C. R. Tzeng, and S. H. Kao, "Endocrine disruptor, dioxin (TCDD)-induced mitochondrial dysfunction and apoptosis in human trophoblastlike JAR cells," Molecular Human Reproduction, vol. 16, no. 5, Article ID gaq004, pp. 361-372, 2010.

[121] I. F. Sevrioukova, "Redox-linked conformational dynamics in apoptosis-inducing factor," Journal of Molecular Biology, vol. 390, no. 5, pp. 924-938, 2009.

[122] L. Misevičien, Z. Anusevičius, J. Šarlauskas, I. F. Sevrioukova, and N. Čnas, "Redox reactions of the FAD-containing apoptosis-inducing factor (AIF) with quinoidal xenobiotics: a mechanistic study," Archives of Biochemistry and Biophysics, vol. 512, no. 2, pp. 183-189, 2011.

[123] Y. C. T. Huang, Z. Li, S. D. Harder, and J. M. Soukup, “Apoptotic and inflammatory effects induced by different particles in human alveolar macrophages," Inhalation Toxicology, vol. 16, no. 14, pp. 863-878, 2004.

[124] P. L. Liu, Y. L. Chen, Y. H. Chen, S. J. Lin, and Y. R. Kou, "Wood smoke extract induces oxidative stress-mediated caspase-independent apoptosis in human lung endothelial cells: role of AIF and EndoG," American Journal of Physiology, vol. 289, no. 5, pp. L739-L749, 2005.

[125] Z. Dagher, G. Garçon, S. Billet et al., "Activation of different pathways of apoptosis by air pollution particulate matter (PM2.5) in human epithelial lung cells (L132) in culture," Toxicology, vol. 225, no. 1, pp. 12-24, 2006.

[126] S. Hussain, L. C. J. Thomassen, I. Ferecatu et al., "Carbon black and titanium dioxide nanoparticles elicit distinct apoptotic pathways in bronchial epithelial cells," Particle and Fibre Toxicology, vol. 7, article 10, 2010.

[127] U. Sydlik, K. Bierhals, M. Soufi, J. Abel, R. P. F. Schins, and K. Unfried, "Ultrafine carbon particles induce apoptosis and proliferation in rat lung epithelial cells via specific signaling pathways both using EGF-R," American Journal of Physiology, vol. 291, no. 4, pp. L725-L733, 2006.

[128] I. Abbas, G. Garçon, F. Saint-Georges et al., "Occurrence of molecular abnormalities of cell cycle in L132 cells after in vitro short-term exposure to air pollution PM2.5," ChemicoBiological Interactions, vol. 188, no. 3, pp. 558-565, 2010.

[129] S. Shishodia and B. B. Aggarwal, "Cyclooxygenase (COX)-2 inhibitor celecoxib abrogates activation of cigarette smokeinduced nuclear factor (NF) $-\kappa \mathrm{B}$ by suppressing activation of $\mathrm{I} \kappa \mathrm{B} \alpha$ kinase in human non-small cell lung carcinoma: correlation with suppression of cyclin D1, COX-2, and matrix metalloproteinase-9," Cancer Research, vol. 64, no. 14, pp. 5004-5012, 2004.

[130] W. H. Kuo, J. H. Chen, H. H. Lin, B. C. Chen, J. D. Hsu, and C. J. Wang, "Induction of apoptosis in the lung tissue from rats exposed to cigarette smoke involves p38/JNK MAPK pathway," Chemico-Biological Interactions, vol. 155, no. 1-2, pp. 31-42, 2005.
[131] S. Soberanes, D. Urich, C. M. Baker et al., "Mitochondrial complex III-generated oxidants activate ASK1 and JNK to induce alveolar epithelial cell death following exposure to particulate matter air pollution," The Journal of Biological Chemistry, vol. 284, no. 4, pp. 2176-2186, 2009.

[132] B. Y. Chin, M. E. Choi, M. D. Burdick, R. M. Strieter, T. H. Risby, and A. M. K. Choi, "Induction of apoptosis by particulate matter: role of TNF- $\alpha$ and MAPK," American Journal of Physiology, vol. 275, no. 5, pp. L942-L949, 1998.

[133] F. Peixoto, J. A. F. Vicente, and V. M. C. Madeira, "Comparative effects of herbicide dicamba and related compound on plant mitochondrial bioenergetics," Journal of Biochemical and Molecular Toxicology, vol. 17, no. 3, pp. 185-192, 2003.

[134] I. O. Kurochkin, M. Etzkorn, D. Buchwalter, L. Leamy, and I. M. Sokolova, "Top-down control analysis of the cadmium effects on molluscan mitochondria and the mechanisms of cadmium-induced mitochondrial dysfunction," American Journal of Physiology, vol. 300, no. 1, pp. R21-R31, 2011.

[135] D. Urich, S. Soberanes, Z. Burgess et al., "Proapoptotic Noxa is required for particulate matterinduced cell death and lung inflammation," The FASEB Journal, vol. 23, no. 7, pp. 20552064, 2009.

[136] N. Podechard, X. Tekpli, D. Catheline et al., "Mechanisms involved in lipid accumulation and apoptosis induced by 1nitropyrene in Hepalc1c7 cells," Toxicology Letters, vol. 206, no. 3, pp. 289-299, 2011.

[137] X. Tekpli, E. Rivedal, M. Gorria et al., "The B[a]P-increased intercellular communication via translocation of connexin43 into gap junctions reduces apoptosis," Toxicology and Applied Pharmacology, vol. 242, no. 2, pp. 231-240, 2010.

[138] X. Tekpli, M. Rissel, L. Huc et al., "Membrane remodeling, an early event in benzo $[\alpha]$ pyrene-induced apoptosis," Toxicology and Applied Pharmacology, vol. 243, no. 1, pp. 68-76, 2010.

[139] "Air pollution and lung cancer," in Air Pollution and Health, J. M. Samet and A. J. Cohen, Eds.S. T. Holgate et al., Ed., pp. 841-564, Academic Press, 1999.

[140] "Carcinogenic responses to air pollutants," in Air Pollution and Health, R. O. McClellan and T. E. Jackson, Eds.S. T. Holgate et al., Ed., pp. 382-413, Academic Press, 1999.

[141] "Carcinogenesis," in Molecular and Biochemical Toxicology, R. C. Smart, S. J. Ewing, and K. D. Loomis, Eds.R. C. Smart and E. Hodgson, Eds., pp. 537-586, John Wiley \& Sons, 1999.

[142] D. Hanahan and R. A. Weinberg, "The hallmarks of cancer," Cell, vol. 100, no. 1, pp. 57-70, 2000.

[143] M. Teranishi, T. Toyooka, T. Ohura, S. Masuda, and Y. Ibuki, "Benzo[a]pyrene exposed to solar-simulated light inhibits apoptosis and augments carcinogenicity," Chemico-Biological Interactions, vol. 185, no. 1, pp. 4-11, 2010.

[144] H. S. Hung, W. J. Wu, Y. W. Cheng, T. C. Wu, K. L. Chang, and H. Lee, "Association of cooking oil fumes exposure with lung cancer: involvement of inhibitor of apoptosis proteins in cell survival and proliferation in vitro," Mutation Research, vol. 628, no. 2, pp. 107-116, 2007.

[145] I. Ferecatu, M. C. Borot, C. Bossard et al., "Polycyclic aromatic hydrocarbon components contribute to the mitochondria-antiapoptotic effect of fine particulate matter on human bronchial epithelial cells via the aryl hydrocarbon receptor," Particle and Fibre Toxicology, vol. 7, article 18, 2010.

[146] A. Q. Truong-Tran, J. Carter, R. E. Ruffin, and P. D. Zalewski, "The role of zinc in caspase activation and apoptotic cell death," BioMetals, vol. 14, no. 3-4, pp. 315-330, 2001.

[147] A. Szuster-Ciesielska, K. Plewka, J. Daniluk, and M. Kandefer-Szerszeń, "Zinc inhibits ethanol-induced HepG2 
cell apoptosis," Toxicology and Applied Pharmacology, vol. 229, no. 1, pp. 1-9, 2008.

[148] J. E. Carter, A. Q. Truong-Tran, D. Grosser, L. Ho, R. E. Ruffin, and P. D. Zalewski, "Involvement of redox events in caspase activation in zinc-depleted airway epithelial cells," Biochemical and Biophysical Research Communications, vol. 297, no. 4, pp. 1062-1070, 2002.

[149] P. Bernardi, A. Krauskopf, E. Basso et al., "The mitochondrial permeability transition from in vitro artifact to disease target," The FEBS Journal, vol. 273, no. 10, pp. 2077-2099, 2006.

[150] C. E. Rexroad and A. M. Powell, "Effect of serum-free co-culture and synchrony of recipients on development of cultured sheep embryos to fetuses," Journal of Animal Science, vol. 69 , no. 5, pp. 2066-2072, 1991.

[151] A. D. Burdick, I. D. Ivnitski-Steele, F. T. Lauer, and S. W. Burchiel, "PYK2 mediates anti-apoptotic AKT signaling in response to benzo[a]pyrene diol epoxide in mammary epithelial cells," Carcinogenesis, vol. 27, no. 11, pp. 23312340, 2006.

[152] M. Chopra, A. M. Dharmarajan, G. Meiss, and D. Schrenk, "Inhibition of UV-C light-induced apoptosis in liver cells by 2,3,7,8-tetrachlorodibenzo-p-dioxin," Toxicological Sciences, vol. 111, no. 1, pp. 49-63, 2009.

[153] L. Al-Anati, J. Högberg, and U. Stenius, "Non-dioxin-like PCBs interact with benzo[a]pyrene-induced p53-responses and inhibit apoptosis," Toxicology and Applied Pharmacology, vol. 249, no. 2, pp. 166-177, 2010.

[154] H. Bayram, K. Ito, R. Issa, M. Ito, M. Sukkar, and K. F. Chung, "Regulation of human lung epithelial cell numbers by diesel exhaust particles," European Respiratory Journal, vol. 27, no. 4, pp. 705-713, 2006.

[155] M. Chopra, M. Gährs, M. Haben, C. Michels, and D. Schrenk, "Inhibition of apoptosis by 2,3,7,8-tetrachlorodibenzo-pdioxin depends on protein biosynthesis," Cell Biology and Toxicology, vol. 26, no. 4, pp. 391-401, 2010.

[156] J. J. Mukherjee, S. Kumar, R. Gocinski, and J. Williams, "Phenolic fraction of tobacco smoke inhibits BPDE-induced apoptosis response and potentiates cell transformation: role of attenuation of p53 response," Chemical Research in Toxicology, vol. 24, no. 5, pp. 698-705, 2011.

[157] M. Hailwood, D. King, and E. Leoz, "Ambient air pollution by polycyclic aromatic hydrocarbons PAH," in Position Paper Annexes, European Commission, 2001.

[158] J. L. Marlowe, Y. Fan, X. Chang et al., "The aryl hydrocarbon receptor binds to E2F1 and inhibits E2F1-induced apoptosis," Molecular Biology of the Cell, vol. 19, no. 8, pp. 3263-3271, 2008.

[159] C. F. A. Vogel, W. Li, E. Sciullo et al., "Pathogenesis of aryl hydrocarbon receptor-mediated development of lymphoma is associated with increased cyclooxygenase-2 expression," American Journal of Pathology, vol. 171, no. 5, pp. 1538-1548, 2007.

[160] A. Ambolet-Camoit, L. C. Bui, S. Pierre et al., "2,3,7,8Tetrachlorodibenzo-p-dioxin counteracts the p53 response to a genotoxicant by upregulating expression of the metastasis marker AGR2 in the hepatocarcinoma cell line HepG2," Toxicological Sciences, vol. 115, no. 2, pp. 501-512, 2010.

[161] H. Sarioglu, S. Brandner, M. Haberger et al., "Analysis of 2,3,7,8-tetrachlorodibenzo-p-dioxin-induced proteome changes in $5 \mathrm{~L}$ rat hepatoma cells reveals novel targets of dioxin action including the mitochondrial apoptosis regulator VDAC2," Molecular and Cellular Proteomics, vol. 7, no. 2, pp. 394-410, 2008.
[162] E. A. Ostrakhovitch, M. R. Lordnejad, F. Schliess, H. Sies, and L.-O. Klotz, "Copper ions strongly activate the phosphoinositide-3-kinase/Akt pathway independent of the generation of reactive oxygen species," Archives of Biochemistry and Biophysics, vol. 397, no. 2, pp. 232-239, 2002.

[163] J. J. Mukherjee, S. K. Gupta, and S. Kumar, "Inhibition of benzopyrene-diol-epoxide (BPDE)-induced bax and caspase- 9 by cadmium: role of mitogen activated protein kinase," Mutation Research, vol. 661, no. 1-2, pp. 41-46, 2009.

[164] N. Agopyan, J. Head, S. Yu, and S. A. Simon, "TRPV1 receptors mediate particulate matter-induced apoptosis," American Journal of Physiology, vol. 286, no. 3, pp. L563L572, 2004.

[165] R. Wu, L. Zhang, M. S. Hoagland, and H. I. Swanson, "Lack of the aryl hydrocarbon receptor leads to impaired activation of AKT/protein kinase B and enhanced sensitivity to apoptosis induced via the intrinsic pathway," Journal of Pharmacology and Experimental Therapeutics, vol. 320, no. 1, pp. 448-457, 2007.

[166] M. Kaimul Ahsan, H. Nakamura, M. Tanito, K. Yamada, H. Utsumi, and J. Yodoi, "Thioredoxin-1 suppresses lung injury and apoptosis induced by diesel exhaust particles (DEP) by scavenging reactive oxygen species and by inhibiting DEPinduced downregulation of Akt," Free Radical Biology and Medicine, vol. 39, no. 12, pp. 1549-1559, 2005.

[167] A. Rasola, M. Sciacovelli, B. Pantic, and P. Bernardi, "Signal transduction to the permeability transition pore," FEBS Letters, vol. 584, no. 10, pp. 1989-1996, 2010.

[168] A. Baeza-Squiban, V. Bonvallot, S. Boland, and F. Marano, "Diesel exhaust particles increase NF- $\kappa \mathrm{B}$ DNA binding activity and c-fos proto-oncogene expression in human bronchial epithelial cells," Toxicology in Vitro, vol. 13, no. 4-5, pp. 817-822, 1999.

[169] S. Shishodia, P. Potdar, C. G. Gairola, and B. B. Aggarwal, "Curcumin (diferuloylmethane) down-regulates cigarette smoke-induced NF- $\kappa \mathrm{B}$ activation through inhibition of $\mathrm{I} \kappa \mathrm{B} \alpha$ kinase in human lung epithelial cells: correlation with suppression of COX-2, MMP-9 and cyclin D1," Carcinogenesis, vol. 24, no. 7, pp. 1269-1279, 2003.

[170] V. Rubio, M. Valverde, and E. Rojas, "Effects of atmospheric pollutants on the Nrf2 survival pathway," Environmental Science and Pollution Research, vol. 17, no. 2, pp. 369-382, 2010.

[171] N. Li, M. I. Venkatesan, A. Miguel et al., "Induction of heme oxygenase-1 expression in macrophages by diesel exhaust particle chemicals and quinones via the antioxidantresponsive element," Journal of Immunology, vol. 165, no. 6, pp. 3393-3401, 2000.

[172] N. Li, J. Alam, M. I. Venkatesan et al., "Nrf2 is a key transcription factor that regulates antioxidant defense in macrophages and epithelial cells: protecting against the proinflammatory and oxidizing effects of diesel exhaust chemicals," Journal of Immunology, vol. 173, no. 5, pp. 34673481, 2004.

[173] D. J. Slebos, S. W. Ryter, M. Van Der Toorn et al., "Mitochondrial localization and function of heme oxygenase-1 in cigarette smoke-induced cell death," American Journal of Respiratory Cell and Molecular Biology, vol. 36, no. 4, pp. 409417, 2007.

[174] D. Morse and A. M. K. Choi, "Heme oxygenase-1: from bench to bedside," American Journal of Respiratory and Critical Care Medicine, vol. 172, no. 6, pp. 660-670, 2005.

[175] B. M. Choi, H. O. Pae, Y. M. Kim, and H. T. Chung, "Nitric oxide-mediated cytoprotection of hepatocytes from 
glucose deprivation-induced cytotoxicity: involvement of heme oxygenase-1," Hepatology, vol. 37, no. 4, pp. 810-823, 2003.

[176] C. S. F. Queiroga, A. S. Almeida, P. M. Alves, C. Brenner, and H. L. A. Vieira, "Carbon monoxide prevents hepatic mitochondrial membrane permeabilization," BMC Cell Biology, vol. 12, article 10, 2011.

[177] L. G. Higgins and J. D. Hayes, "Mechanisms of induction of cytosolic and microsomal glutathione transferase (GST) genes by xenobiotics and pro-inflammatory agents," Drug Metabolism Reviews, vol. 43, no. 2, pp. 92-137, 2011.

[178] H. Raza, "Dual localization of glutathione S-transferase in the cytosol and mitochondria: implications in oxidative stress, toxicity and disease," The FEBS Journal, vol. 278, no. 22, Article ID 10.1111/j.1742-4658.2011.08358.x, pp. 4243 4251, 2011.

[179] K. K. Lee, M. Shimoji, Q. S. Hossain, H. Sunakawa, and Y. Aniya, "Novel function of glutathione transferase in rat liver mitochondrial membrane: role for cytochrome c release from mitochondria," Toxicology and Applied Pharmacology, vol. 232, no. 1, pp. 109-118, 2008.

[180] N. Li, M. Hao, R. F. Phalen, W. C. Hinds, and A. E. Nel, "Particulate air pollutants and asthma: a paradigm for the role of oxidative stress in PM-induced adverse health effects," Clinical Immunology, vol. 109, no. 3, pp. 250-265, 2003.

[181] "Particle-mediated extracellular oxidative stress in the lung," in Particle Toxicology, F. J. Kelly and I. S. Mudway, Eds.K. Donaldson and P. Borm, Eds., pp. 89-117, CRC Press, 2007.

[182] N. Li, M. Wang, T. D. Oberley, J. M. Sempf, and A. E. Nel, "Comparison of the pro-oxidative and proinflammatory effects of organic diesel exhaust particle chemicals in bronchial epithelial cells and macrophages," Journal of Immunology, vol. 169, no. 8, pp. 4531-4541, 2002.

[183] R. Barouki, "Linking long-term toxicity of xeno-chemicals with short-term biological adaptation," Biochimie, vol. 92, no. 9, pp. 1222-1226, 2010. 

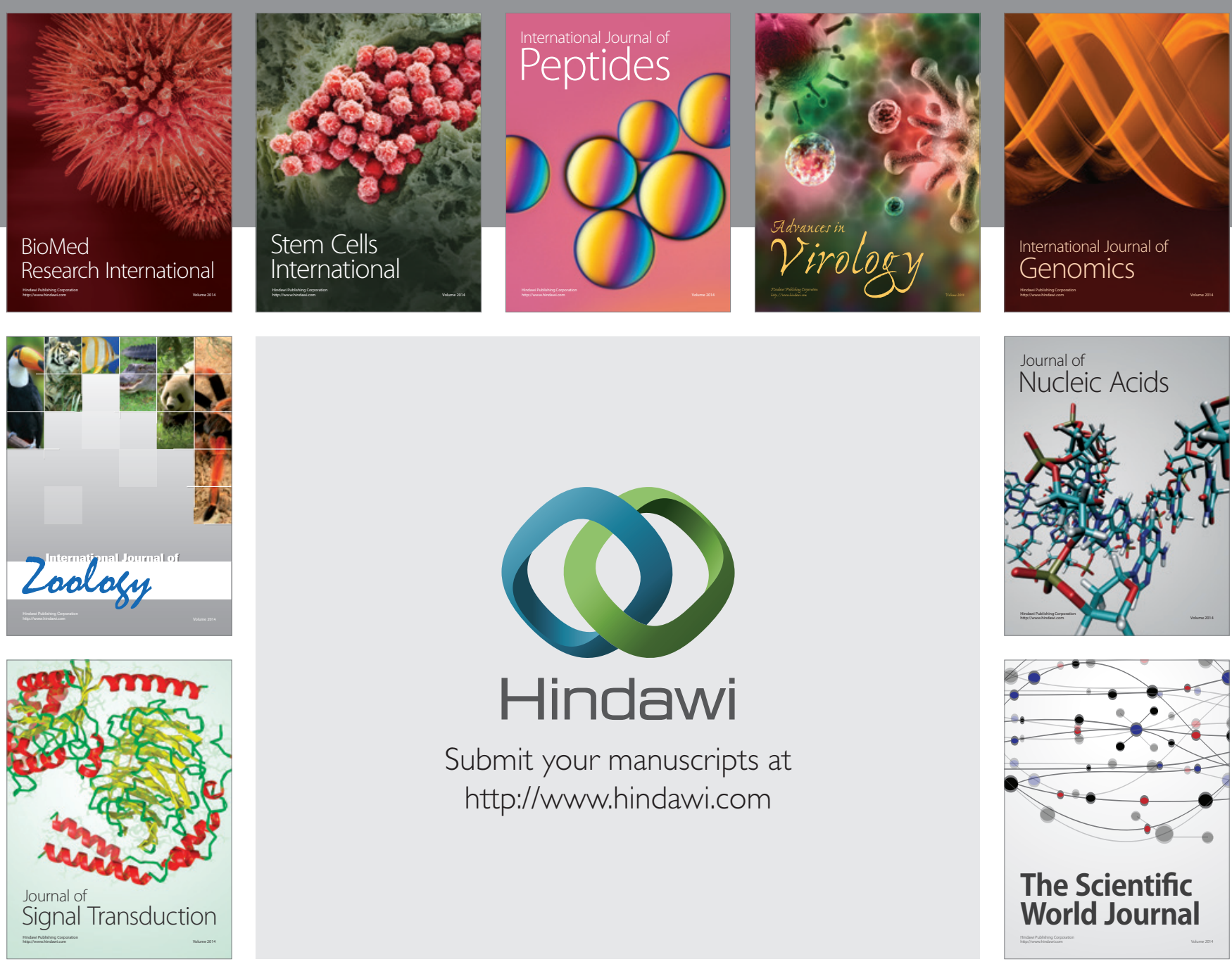

Submit your manuscripts at

http://www.hindawi.com
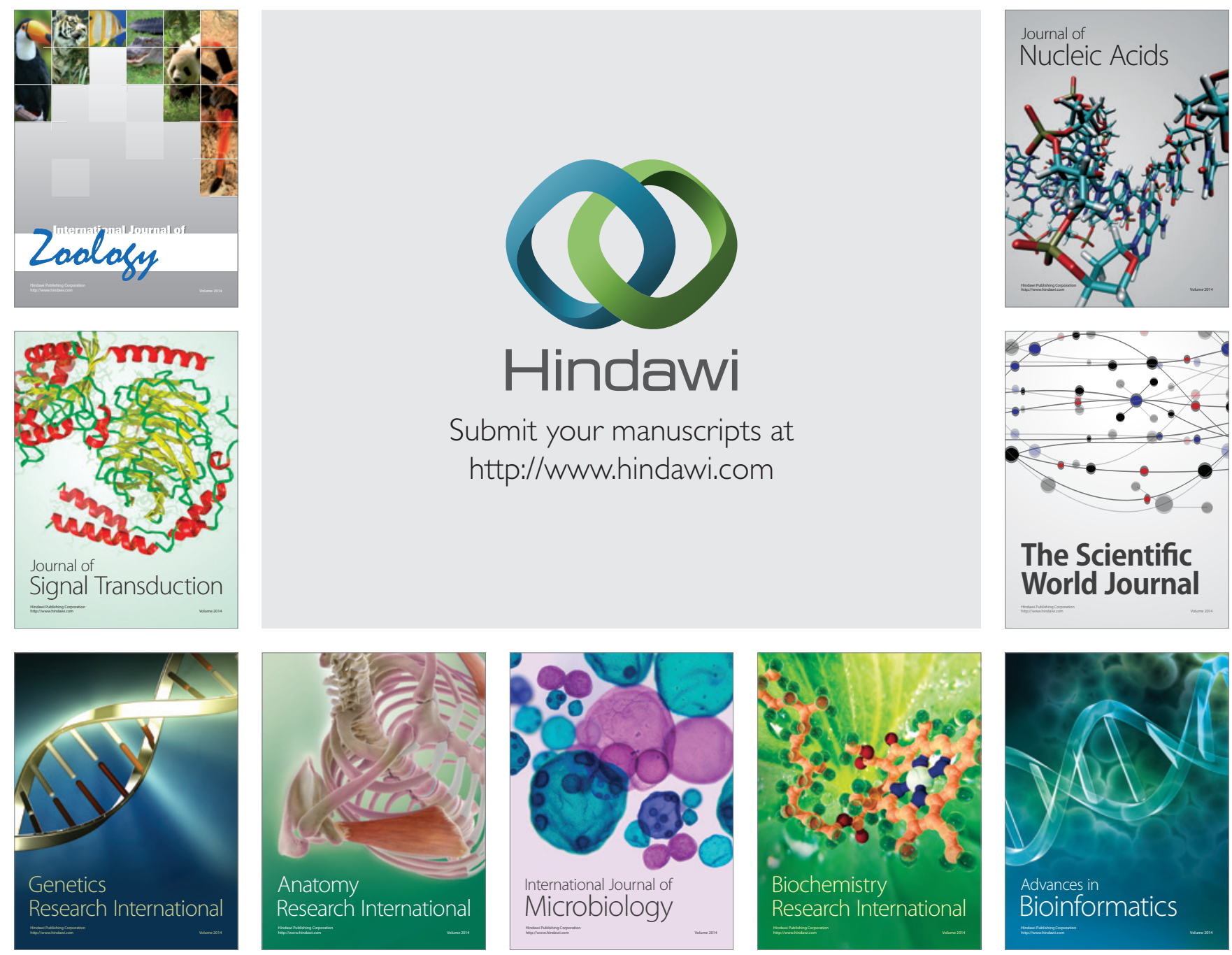

The Scientific World Journal
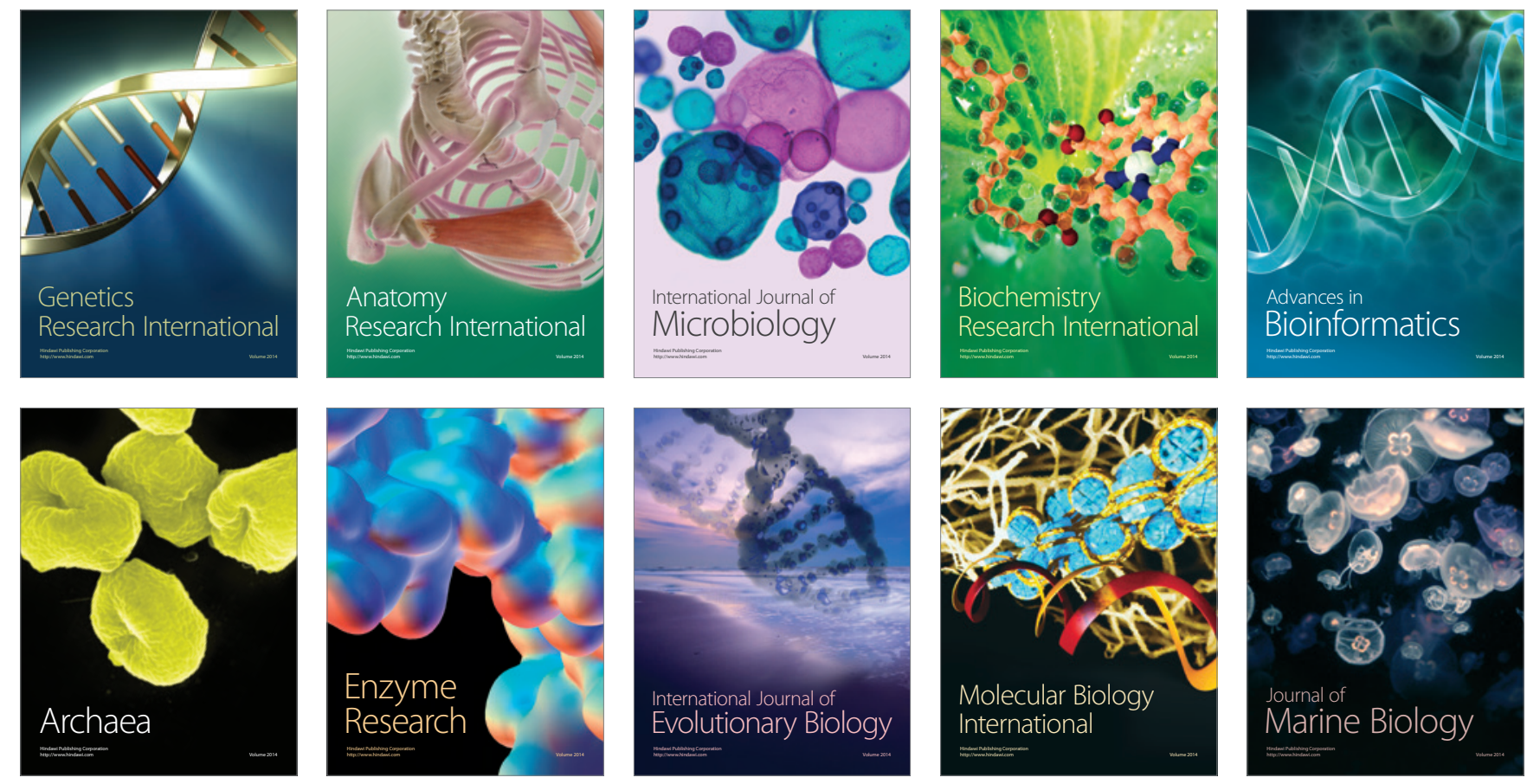